University of Chicago Law School

Chicago Unbound

Journal Articles

Faculty Scholarship

2015

\title{
Judicial Independence and the Rationing of Constitutional Remedies
}

Aziz Huq

Follow this and additional works at: https://chicagounbound.uchicago.edu/journal_articles

Part of the Law Commons

\section{Recommended Citation}

Aziz Huq, "Judicial Independence and the Rationing of Constitutional Remedies," 65 Duke Law Journal 1 (2015).

This Article is brought to you for free and open access by the Faculty Scholarship at Chicago Unbound. It has been accepted for inclusion in Journal Articles by an authorized administrator of Chicago Unbound. For more information, please contact unbound@law.uchicago.edu. 


\title{
Duke Law Journal
}

\section{JUDICIAL INDEPENDENCE AND THE RATIONING OF CONSTITUTIONAL REMEDIES}

\begin{abstract}
AZIZ Z. HUQ $\dagger$
ABSTRACT

This Article analyzes the doctrinal instruments federal courts use to allocate scarce adjudicative resources over competing demands for constitutional remedies. It advances two claims. First, a central, hitherto underappreciated, doctrinal instrument for rationing judicial resources is a demand that most constitutional claimants demonstrate that an official violated an exceptionally clear, unambiguous constitutional rule-that is, not only that the Constitution was violated, but that the violation evinced a demanding species of fault. This fault rule first emerged in constitutional tort jurisprudence. It has diffused to the suppression and postconviction review contexts. The Article's second claim is that fault-based rationing of constitutional remedies flows, to an underappreciated degree, from an institutional commitment to judicial independence. Federal courts have developed branch-level autonomy, along with distinctly institutional interests, over the twentieth century. These interests are inconsistent with the vindication of many individualized constitutional claims. Although
\end{abstract}

Copyright @ 2015 Aziz Z. Huq.

$\dagger$ Professor of Law, University of Chicago Law School. I received terrific feedback on an earlier draft of this paper at the University of Buffalo SUNY Law School. I am also especially grateful to Anya Bernstein, Guyora Binder, Samuel Bray, Luis Chiesa, Zach Clompton, Jim Gardner, Genevieve Lakier, Marin Levy, Anji Malhotra, Tony O'Rourke, Eve Primus, John Rappaport, Mike Seidman, Neil Siegel, Matthew Steilen, and Rick Su for their generous and illuminating responses and comments, which have saved me from many errors. Michael Fishman, Jyoti Jindal, and other editors at the Journal did a superlative job on this piece, providing excellent editing and substantive advice. I'm grateful for their care and patience. All remaining errors are mine alone. I am also pleased to acknowledge the support of the Frank Cicero, Jr. Faculty Fund. 
ideological preferences and changing socioeconomic conditions have had well-recognized influences on the path of constitutional remedies, I argue that the judiciary's institutional preferences have also played a large role. This causal link between judicial independence and remedial rationing raises questions about federal courts' function in the Separation of Powers.

\section{TABLE OF CONTENTS}

Introduction 3

I. Fault and the Rationing of Constitutional Remedies

A. The Remedial Dispensation for Individualized Constitutional Wrongs

B. Fault in Constitutional Tort Law............................................20

1. Fault as the Operative Principle of Qualified

Immunity

2. Fault's Spillovers from Constitutional Tort Doctrine........25

C. Fault and the Exclusionary Rule ..........................................29

D. Fault in Postconviction Habeas Jurisprudence......................34

II. The Causal Link Between Remedial Rationing and Judicial

Independence .40

A. Fault as a Judicial or a Congressional Rule ..........................41

1. Fault as a Legislative Imposition?

2. Fault as an Outcome of Litigant Incentives?

B. Judicial Ideology as a Cause of Remedial Rationing...........46

1. Qualified Immunity

2. Postconviction Review

3. The Exclusionary Rule.

C. Circumstantial Evidence of the Institutional Roots of the Fault Rule

1. The Judiciary's Institutional Interest in Caseload

Management

2. Caseload Management in the Era of Fault .........................58

D. Institutional Interests and the Boundaries of the Fault

Rule

1. Exceptions to the Fault Rule

2. Judicial Interests as a Determinant of the Contours of Fault

III. Implications of the Fault Rule for Constitutional Remedies ........70

A. Distributive Implications ........................................................70

B. Implications for the Separation of Powers ............................75 


\section{INTRODUCTION}

Article III adjudication is a scarce good. ${ }^{1}$ This is not just a function of rising caseloads, statutory as well as constitutional, outstripping federal courts' capacity. ${ }^{2}$ It also flows inexorably from the fact that settled constitutional rules are daily broken. Between the 1950s and the 1970s, the Supreme Court fashioned a thick network of constitutional rules to bind police officers, prison officials, prosecutors, state trial court judges, and frontline bureaucrats. ${ }^{3}$ These rules are often observed now only in the breach. Even in the wellstructured, closely supervised context of state criminal courts, there is ample evidence that constitutional rights are systemically flouted. ${ }^{4}$ Some municipal justice systems may stay solvent by illegally depriving citizens of basic liberties. ${ }^{5}$ On our nation's streets, constitutional violations are routinized in some urban neighborhoods. ${ }^{6}$ We simply

1. Judicial recognition of this point is frequent. See, e.g., Ashcroft v. al-Kidd, $131 \mathrm{~S}$. Ct. 2074, 2080 (2011) ("Courts should think carefully before expending scarce judicial resources to resolve difficult and novel questions of constitutional or statutory interpretation that will have no effect on the outcome of the case."); see also Marin K. Levy, Judicial Attention As A Scarce Resource: A Preliminary Defense of How Judges Allocate Time Across Cases in the Federal Courts of Appeals, 81 GEO. WASH. L. REV. 401, $402 \&$ nn.1-5 (2013) (collecting statements by judges and numerical evidence of increasing caseload pressures).

2. Between 1990 and 2012, federal district courts' combined civil and criminal caseloads rose by 31 percent, whereas the number of judges rose by 17.7 percent, Judicial Facts and Figures 2012 Table 6.1: Total Civil and Criminal Cases Filed, Terminated, and Pending (Including Transfers), U.S. COURTS, http://www.uscourts.gov/file/13382/download [http://perma .cc/523X-D26T].

3. For a celebratory account, see generally MORTON J. HOROWITZ, THE WARREN Court AND THE PURSUIT OF JUSTICE (1998).

4. See, e.g., AM. BAR ASs'N Standing COMM. ON Legal AID \& Indigent DEFENDANTS, GIDEON'S BROKEN PROMISE: AMERICA's CONTINUING QUEST FOR EQUAL JUSTICE, at iv-v (2004), http://www.americanbar.org/content/dam/aba/administrative/legal_aid_ indigent_defendants/ls_sclaid_def_bp_right_to_counsel_in_criminal_proceedings.authcheckdam .pdf [http://perma.cc/6JVP-PAZ4] (finding that many indigents still lack adequate representation and that legal aid programs are woefully underfunded); see also Eve Brensike Primus, A Structural Vision of Habeas Corpus, 98 CALIF. L. REV. 1, 16-23 (2010) (cataloging many more entrenched practices in state criminal courts that violate defendants' constitutional rights).

5. See, e.g., Monica Davey, Ferguson One of 2 Missouri Suburbs Sued Over Gauntlet of Traffic Fines and Jail, N.Y. TIMES, Feb. 8, 2015, at A8 (describing law suit challenging municipal policies resulting in routine jailing of the poor). Alice Goffman's recent ethnography of innercity Philadelphia is also replete with examples of how basic liberty rights are routinely violated by urban criminal justice systems. See generally ALICE GOFFMAn, ON THE RUN: FugITIVE LifE IN AN AMERICAN CITY (2014).

6. A 2002 Bureau of Justice national survey estimated that police used force against individuals on 664,500 instances annually, and that approximately 587,000 of those usages were perceived to be excessive. MATTHEW R. DUROSE et AL., BUREAU OF Justice Statistics, U.S. 
have no reliable way to know how often zoning officials, welfare bureaucrats, or prison guards act on unconstitutional grounds or discard mandatory procedures.

So mundane and so frequent are violations of settled constitutional rules that federal courts plainly lack capacity to offer relief in all cases. True, federal courts need write no new law to resolve these cases. But even if the law is clear, there are, as Blackstone observed, "above a hundred of our lawsuits [that] arise from disputed facts, for one in which the law is doubted of." constitutional rules were wrought with crystalline transparency, the cost of factual adjudication means that not even a fraction of constitutional violations could be resolved in federal court. For this reason alone, the supposedly "settled and invariable principle" of public law, famously articulated by Chief Justice John Marshall, "that every right, when withheld, must have a remedy, and every injury its proper redress" ${ }^{\prime 8}$ is increasingly elusive.

Yet if some rationing of constitutional remedies is inevitable, how is it to be done-and, as importantly, by whom? This Article analyzes these how and who questions prompted by remedial scarcity in constitutional law. It advances two claims. First, the Court has developed a gatekeeping rule of fault for individualized constitutional remedies ranging from constitutional tort to habeas to the exclusionary rule. In a previous article, I identified in passing this transubstantive migration, but did not comprehensively analyze its evolution or effects. ${ }^{9}$ Building on that work here, I develop a more extensive account of fault's role in constitutional remediation. Second, I contend that standard accounts of the narrowing of constitutional remedies since the $1980 \mathrm{~s}^{10}$ have omitted an important

Dep't of Justice, Contacts Between Police and the Public, 2005, at 8 (2007), http://www.bjs.gov/content/pub/pdf/cpp05.pdf [http://perma.cc/6ZW8-TJDT].

7. 3 WiLLIAM BLACKSTONE, COMMENTARIES $* 330$ (spelling adjusted).

8. Marbury v. Madison, 5 U.S. (1 Cranch) 137, 147 (1803). In this passage, Chief Justice Marshall was discussing the common-law writ system, in which such a one-to-one correspondence between rights and remedies existed.

9. Aziz Z. Huq, Habeas and the Roberts Court, 81 U. CHI. L. REv. 519, 582 (2014) (discussing the role of fault). A student note published later the same year also noted commonality of approaches across remedial domains, largely to criticize rather than to explain. See Thomas K.S. Fu, Note, Against Doctrinal Convergence in Constitutional Remedies, 10 STAN. J. C.R. \& C.L. 293, 303-04 (2014).

10. The standard accounts focus on ideological change within the Court. See, e.g., David Rudovsky, Running in Place: The Paradox of Expanding Rights and Restricted Remedies, 2005 U. ILL. L. REV. 1199, 1239. 
factor: Judicial independence both facilitates and motivates the faultbased gatekeeping system in constitutional remedies. Of course, factors such as judicial ideology, the politics of crime, and beliefs about the moral worth of relevant rights-holding populations have played a role in crafting our law of constitutional remedies. In addition to these factors, I argue, the institutional independence of Article III tribunals can impede the realization of constitutional rights.

The Article's first contribution is to show how a gatekeeping fault rule emerged and assumed a supervisory role in titrating most individualized constitutional remedies. ${ }^{11}$ The term "fault" is a legal term of art requiring some definition. ${ }^{12}$ Following the Supreme Court, I use fault in a specific, narrow sense. In this constitutional remedies context, fault is used to pick out cases in which it was not possible for the offender to "reasonably believe" they were acting consistent with the Constitution. ${ }^{13}$ Identifying a mere constitutional violation is not enough. A fault-based gatekeeping rule requires constitutional litigants to have suffered a self-evident violation of a clear and unambiguously applicable constitutional rule. ${ }^{14}$ The magnitude of the legal error must be substantial.

Fault so defined is a familiar element of constitutional tort doctrine in the form of the qualified immunity defense, and also a (less noticed) dimension of municipal liability doctrine. ${ }^{15}$ Fault has also spilled over into the substantive law of certain constitutional provisions that commonly form the basis of constitutional tort actions, such as the Due Process Clause. Less noticed still is fault's contagious

11. See infra Part I (extending and substantiating this account).

12. Cf. Kyron Huigens, Solving the Apprendi Puzzle, 90 GEO. L.J. 387, 419-20 (2002) (exploring the overlapping meanings of fault and culpability).

13. John C. Jeffries, Jr., Compensation for Constitutional Torts: Reflections on the Significance of Fault, 88 MICH. L. REV. 82, 98 (1989).

14. One might reasonably protest that the Court should employ a term such as "unreasonable fault," but it has not done so. I shall not confuse matters by diverting from its terminology.

15. Professor John Jeffries has written a series of important articles identifying and defending the regulative role of fault in constitutional tort. See Jeffries, supra note 13, at 96-101; see also John C. Jeffries, Jr., Disaggregating Constitutional Torts, 110 YALE L.J. 259, 263 (2000) [hereinafter Jeffries, Disaggregating]; John C. Jeffries, Jr., In Praise of the Eleventh Amendment and Section 1983, 84 VA. L. REV. 47, 49 (1998); John C. Jeffries, Jr., The Liability Rule for Constitutional Torts, 99 VA. L. REV. 207, 209 (2013) (presenting "a unified theory of constitutional torts"); John C. Jeffries, Jr., The Right-Remedy Gap in Constitutional Law, 109 YALE L.J. 87, 98-100 (1999). Jeffries, however, has not extended the analysis beyond the constitutional tort context as this Article seeks to do. 
spread into contiguous remedial contexts and even some substantivelaw domains. ${ }^{16}$ Since the late 1980 s, it has come to dominate the law of postconviction relief for prisoners under 28 U.S.C. $§ 2254 .{ }^{17}$ Further, it is increasingly the main gatekeeping rule for criminal defendants seeking a suppression remedy after a Fourth or Fifth Amendment violation. ${ }^{18}$ One consequence of fault's ascendency within the doctrinal framework of constitutional remedies is that the modal question in constitutional litigation today is no longer whether the Constitution has been violated. Rather, it is whether the violation was sufficiently clear and self-evident to warrant expending scarce judicial resources.

Why has this version of fault, which hinges on the violation's clarity at the time it occurred and which plainly favors the state, become the organizing principle of remedial rationing? The Article's second contribution is a causal hypothesis: One of the important, yet wholly overlooked, causes of the fault-based rationing system for constitutional remedies is the institutional independence of the judiciary. ${ }^{19}$ Leading accounts of constitutional remedies stress the role of ideological interests and historical circumstances in shaping the path of constitutional remedies. ${ }^{20} \mathrm{I}$ do not revisit those claims. Rather, I add to those accounts by focusing on the important role that the judiciary's institutional interests have played in shaping constitutional remedies. I aim to show how an account of recent constitutional doctrine without accounting for institutional interests is incomplete.

16. In charting the spillover of fault to the definition of substantive rights, I confess to stepping beyond my remedial remit in order to illuminate the doctrine better.

17. The law of 28 U.S.C. $\S 2255$ largely tracks that of $\S 2254$.

18. See infra Part I.C.

19. By referring to judicial independence, I do not refer to the sense of "decisional independence of individual judges" but in the sense of "the institutional independence of the judiciary as a whole." See Vicki C. Jackson, Packages of Judicial Independence: The Selection and Tenure of Article III Judges, 95 GEO. L.J. 965, 967 (2007).

20. See, e.g., Peter Arenella, Rethinking the Functions of Criminal Procedure: The Warren and Burger Courts' Competing Ideologies, 72 GEO. L.J. 185, 247 (1983) (arguing that the Burger Court favored "judicial deregulation of state and federal criminal justice officials," and showed "hostility to fair process norms that impair the state's capacity to detect and punish the factually guilty"); Alan M. Dershowitz \& John Hart Ely, Harris v. New York: Some Anxious Observations on the Candor and Logic of the Emerging Nixon Majority, 80 YALE L.J. 1198, 1227 (1971) (noting the "[i]deological ebb and flow" in the Court's criminal procedure jurisprudence); Louis Michael Seidman, Factual Guilt and the Burger Court: An Examination of Continuity and Change in Criminal Procedure, 80 COLUM. L. REV. 436, 437 (1980) (arguing that the "Burger Court is undoubtedly more interested than its predecessor in using the criminal process to effect broadscale crime prevention and control" but also noting that these aspects of the Court had been overstated). 
In particular, I propose that interests in judicial economy and prestige, in addition to ideological priorities in favor (or against) certain litigants, play a role.

Supplementing leading accounts of constitutional remedies with such institutional considerations is of no mere antiquarian interest. It has contemporary ramifications. An account of remedial rationing based on ideological factors alone implies that changing the Court's composition would lead to more available remedies. I predict otherwise. Rather, even a high court with a higher proportion of Democratic appointees would not behave all that differently. For whatever partisan flag they try to occlude, Justices of left and right alike have historically evinced a powerful allegiance to the institutional concerns of the Article III courts.

The evidence I present for a causal link between judicial independence and remedial rationing is circumstantial. As a threshold matter, I demonstrate that the two standard reasons for explaining remedial rationing are incomplete. First, legislative action alone cannot explain the current doctrinal regime for redressing violations of individual constitutional rights. In many statutory domains, including civil rights, Congress has played a large role in creating and modifying remedies. ${ }^{21}$ Not so with many strictly constitutional remedies. Although Congress has influenced some remedial regimes, its most important interventions have come too late to have causal force, and they too often merely codified previously articulated judicial preferences. ${ }^{22}$ Second, ideological preferences over constitutional rights and rights-holding populations do not explain all doctrinal change. To a greater extent than appreciated, constitutional remedies have been narrowed by ideologically mixed coalitions of the Court. The poverty of both standard accounts points to the need for alternative explanations, and opens the way for a new accounting.

I supplement standard accounts by highlighting the role of the judiciary's institutional interests. ${ }^{23}$ The positive case for linking

21. See, e.g., Civil Rights Act of 1991, Pub. L. No. 102-166, 105 Stat. 1077 (1991) ("The Congress finds that... additional remedies under Federal law are needed to deter unlawful harassment and intentional discrimination in the workplace ....").

22. See Huq, supra note 9, at 531 n.44; see also infra text accompanying notes 216-218.

23. For an empirical account of the judiciary's institutional development emphasizing the vast gains it has made in legitimacy and authority, see Kevin McGuire, The Institutionalization of the U.S. Supreme Court, 12 POL. ANALYSIS 128, 141 (2004). For a historical account also illustrating the steep gradient in institutional growth, see JUSTIN CROWE, BUILDING THE JUDICIARY: LAW, COURTS, AND THE POLITICS OF INSTITUTIONAL DEVELOPMENT 224 (2012). 
remedial rationing and judicial independence starts with the context in which the doctrine changed. The gatekeeping role of fault crystallized largely in the early 1980s. In this era, new pressures impinged on the Article III judiciary. These pressures arose from the contemporaneous rise of mass incarceration, which created metastasizing demands for criminal adjudication and postconviction review. ${ }^{24}$ Recent empirical work also shows that "institutional" ${ }^{25}$ considerations often shape the Justices' behavior, an influence that to date has been largely ignored. Indeed, Justices have explicitly, if occasionally, identified institutional interests as a motive for narrowing constitutional remedies. ${ }^{26}$ Finally, an analysis of the remedial contexts in which the Court has not extended the fault rule supports the inference that institutional incentives are at work in shaping the doctrine.

This causal vector-from the judiciary's institutional interests to remedial constriction-is not only missing from previous accounts, but is roughly the inverse of one standard account in the literature, offered by the late Professor William Stuntz. According to Stuntz, it was the generosity of federal constitutional remediation that induced legislatures to tilt toward more punitive policies. ${ }^{27}$ While recognizing this account as theoretically sophisticated and parsimonious, I supplement previous empirical criticisms $^{28}$ by arguing that constitutional doctrine responded to-and did not cause-the massive changes in the volume and punitiveness of American criminal justice systems starting in the 1970s, with the judiciary's institutional interests playing an important mediating role.

24. See generally Todd R. Clear \& NAtasha A. Frost, The Punishment ImPerative: THE Rise AND FALl OF MASS INCARCERATION IN AMERICA (2014).

25. Thomas M. Keck, Party, Policy, or Duty: Why Does the Supreme Court Invalidate Federal Statutes?, 101 AM. POL. SCI. REV. 321, 323 (2007).

26. See, e.g., Brown v. Allen, 344 U.S. 443, 537 (1953) (Jackson, J., concurring) ("It must prejudice the occasional meritorious application to be buried in a flood of worthless ones. He who must search a haystack for a needle is likely to end up with the attitude that the needle is not worth the search.").

27. See William J. Stuntz, The Uneasy Relationship Between Criminal Procedure and Criminal Justice, 107 YALE L.J. 1, 64 (1997) [hereinafter Stuntz, Uneasy Relationship]; see also William J. Stuntz, The Pathological Politics of Criminal Law, 100 MICH. L. REV. 505, 559-65 (2001) (using the void-for-vagueness doctrine as an example of this dynamic).

28. For a devastating analysis of the empirics of Stuntz's claims, see Stephen J. Schulhofer, Criminal Justice, Local Democracy, and Constitutional Rights, 111 MICH. L. REV. 1045, 1049-60 (2013). 
The principal aims of this Article are descriptive: the identification and diagnosis of an immanent rationing principle governing much constitutional remedies doctrine, and the development of an argument, supported by several strands of circumstantial evidence, of one important causal force. This analysis, important on its own terms, also clears ground for normative reevaluation of what role federal courts can play, or ought to play, in the enforcement of settled constitutional rules. Perhaps most importantly, it should unsettle some persistently unexamined truisms of constitutional law. Conventional Separation of Powers jurisprudence takes for granted that the independence of Article III judges exists "'not to benefit the judges,' but 'as a limitation imposed in the public interest'... by helping to secure an independence of mind and spirit necessary if judges are 'to maintain that nice adjustment between individual rights and governmental powers which constitutes political liberty.", ${ }^{29}$ As recently as March 2015, members of the Court have pronounced without contradiction that "the 'separation of powers' ... [is] essential to the protection of individual liberty." ${ }^{30}$ This truism assumes an alignment between judicial incentives and the vindication of "individual rights" and "political liberty." But Separation of Powers theory is peculiarly silent on how that alignment might occur, or why institutional incentives would necessarily conduce to the vindication of rights. ${ }^{31}$ This Article's account of remedial rationing in the shadow of judicial independence demonstrates that judicial incentives and the interests of constitutional-rights holders need not run together. Instead, they not only can, but do, diverge sharply as a result of the judiciary's

29. United States v. Hatter, 532 U.S. 557, 568 (2001) (citations omitted); accord Evans v. Gore, 253 U.S. 245, 249 (1920) ("The Constitution was framed on the fundamental theory that a larger measure of liberty and justice would be assured by vesting the three great powers, the legislative, the executive, and the judicial, in separate departments . ...").

30. Perez v. Mortg. Bankers Ass'n, 135 S. Ct. 1199, 1215 (2015) (Thomas, J., concurring) (quoting Stern v. Marshall, 131 S. Ct. 2594, 2608-09 (2011)).

31. The failure of traditional Separation of Powers theory to specify a persuasive causal channel for claimed effects of institutional design has been noted in other contexts. For an application in the context of legislative/executive relations, see, for example, Daryl J. Levinson \& Richard H. Pildes, Separation of Parties, Not Powers, 119 HARV. L. Rev. 2311, 2324-25 (2006) ("[T]he political interests of elected officials generally correlate more strongly with party than with branch .... [P] arty is likely to be the single best predictor of political agreement and disagreement."). See also Aziz Z. Huq, Libertarian Separation of Powers, 8 N.Y.U. J.L. \& LIBERTY 1006, 1012 (2014) (expressing skepticism about the necessary connection between the functional separation of different elements of governmental power and the promotion of liberty). 
institutional interests in prestige and docket management. These can stand starkly at odds with the rights-holding public's concerns. This gap should provoke hesitation about canonical Separation of Powers assumptions.

This Article's analysis is limited along three dimensions. First, I focus here solely on constitutional claims, not statutory claims, ${ }^{32}$ and consider only courts' power to issue relief that directly responds to a constitutional wrong. ${ }^{33}$ Such cases merit analysis because they comprise a significant slice of the federal docket. ${ }^{34}$ Second, my argument concerns federal courts as axiomatic loci for the vindication of federal constitutional rights. ${ }^{35}$ Of course, federal courts often stay their hand to allow state courts a first effort at resolving a constitutional issue, ${ }^{36}$ while state courts can also play a role in

32. Parallel accounts might be told in regard to other domains of public law. See, e.g., J. Maria Glover, The Disappearing Shadow of Public Law, 125 YALE L.J. (forthcoming 2015). Moreover, it is possible that the Court acts as if it has a heightened measure of policymaking discretion when it comes to constitutional remedies, as opposed to statutory forms with respect to which it purports to hew to congressional will. For this reason, the area of constitutional remedies with which I am concerned represents a particularly fertile perspective on judicial preferences and behavior.

33. My focus on remedies means that I also do not attend to other devices for limiting the flow of claims or reducing the costs of adjudication in this domain. One might also look at attorney's fees. For example, in Buckcannon Board and Care Home, Inc. v. West Virginia Department of Health and Human Services, 532 U.S. 598, 605 (2001), the Court interpreted the Civil Rights Attorney's Fees Award Act of 1976 to permit fees awards only when a judgment, court-approved settlement, or some other order formally changed the legal relationship between the parties. In an equitable suit challenging an institutional practice after Buckcannon, defendants can litigate equitable claims to the point of judgment, and then avoid fees by consenting to the relief requested.

34. Prisoner cases, for example, take up about a fifth of the number of civil suits filed in district courts in recent years. See U.S. District Courts - Judicial Business 2013, U.S. CourTs, at tbl. 3, http://www.uscourts.gov/Statistics/JudicialBusiness/2013/us-district-courts.aspx [http:// perma.cc/CBV6-PZ8L].

35. Hence, this Article does not address the different ways in which structural constitutional values might be enforced. Cf. Aziz Z. Huq, Standing for the Structural Constitution, 99 VA. L. REV. 1435, 1499-1514 (2013) (analyzing the choice between public and private enforcement of structural constitutional values).

36. See, e.g., Younger v. Harris, 401 U.S. 37, $46-47$ (1971) (limiting the availability of pretrial federal injunctive relief against state criminal process). The role of state courts was especially important in the early Republic. See Alfred Hill, Constitutional Remedies, 69 COLUM. L. REV. 1109, 1142 (1969) ("Despite their remedial deficiencies, it was the state courts that were looked to [before 1875] for the vindication of constitutional rights, subject to review by the Supreme Court."). For an example of path-marking state-court action on constitutional rights, see Goodridge v. Department of Public Health, 798 N.E.2d 941, 1004-05 (Mass. 2003) (recognizing a right to same-sex marriage under state constitutional law). 
vindicating constitutional entitlements. ${ }^{37}$ But even if state courts are "presumed competent to resolve federal issues," 38 they cannot play a comprehensive role. State courts cannot issue mandatory writs against federal officials, ${ }^{39}$ or free a federal prisoner from unlawful confinement. $^{40}$ Further, federal courts by "consensus" play a dominant role today in constitutional remediation. ${ }^{41}$ Enforcement of constitutional rights by the executive branch, while important, is also inconstant. ${ }^{42}$ Finally, this Article analyzes the remedial function of the federal courts, not its distinct role in defining rights. ${ }^{43}$ This focus on constitutional remedies builds upon an emerging body of scholarship recognizing that questions of "what to do about a completed or threatened violation of law" are "distinct from the question of whether there has been or is about to be a violation." 44

37. Miller v. Fenton, 474 U.S. 104, 117 (1985) (expressing "confidence that state judges, no less than their federal counterparts, will properly discharge their duty to protect the constitutional rights of criminal defendants"); see also Giovanna Shay, The New State Postconviction, 46 AKRON L. REV. 473, 475 (2013) (noting that state postconviction proceedings "are being forced to assume a new role in the development of federal constitutional criminal procedure").

38. Chick Kam Choo v. Exxon Corp., 486 U.S. 140, 150 (1988).

39. McClung v. Silliman, 19 U.S. (6 Wheat.) 598, 605 (1821) (holding that a federal official's "conduct could only be controlled by the power that created him").

40. Tarble's Case, 80 U.S. (13 Wall.) 397, 411-12 (1871); Ableman v. Booth, 62 U.S. (21 How.) 506, 524 (1859).

41. Ann Woolhandler, The Common Law Origins of Constitutionally Compelled Remedies, 107 YALE L.J. 77, 81, 111-25 (1997) (arguing that there is a "consensus that the federal courts should administer a federalized set of rights and remedies for federal constitutional rights").

42. The executive branch, for example, wields large authority over determinations of how laws are enforced and defended from constitutional attack, supplying a nonjudicial forum for rights vindication. $C f$. Aziz Z. Huq, Enforcing (but not Defending) 'Unconstitutional' Laws, 98 VA. L. REV. 1001, 1001-02 (2012) (discussing modalities of executive enforcement of the Constitution). A 1994 statute also vests the Department of Justice with authority to force institutional reform in police departments. 42 U.S.C. $§ 14141$ (2012) (authorizing the Justice Department to seek injunctive relief against departments with a pattern of unconstitutional conduct). But $\S 14141$ 's deployment is neither uniform nor comprehensive. Even with executive aid, the federal judiciary still provides a unique fulcrum from which rights can be leveraged.

43. For examples of scholarship that explores how courts define rights in optimal or suboptimal ways, compare Lawrence Gene Sager, Fair Measure: The Legal Status of Underenforced Constitutional Norms, 91 HARV. L. REV. 1212, 1215 (1978) (describing and criticizing underenforcement of equal protection norms), with Emily Sherwin, Judges as Rulemakers, 73 U. CHI. L. REV. 919, 919 (2006) (defending the common-law method of generating constitutional rules).

44. Douglas Laycock, How Remedies Became A Field: A History, 27 REV. LITIG. 161, 16465 (2008). For work focusing on the interaction between remedial design and the substance of constitutional rights, see, for example, Orin S. Kerr, Fourth Amendment Remedies and Development of the Law: A Comment on Camreta v. Greene and Davis v. United States, 2011 CATO SuP. CT. REV. 237, 244-45 (considering interactions between changes in exclusionary rule 
The argument proceeds in three stages. Part I establishes the centrality of fault in the rationing of three individualized constitutional remedies-money-damages actions, postconviction relief from unconstitutionally imposed criminal sentences, and the suppression of evidence obtained in violation of the Fourth or Fifth Amendment. Part II turns to the etiology of fault's regulative role. I argue that the rise of fault cannot be ascribed solely to Congress or the shifting ideological preferences of the Justices-perhaps the two most obvious alternatives. I then offer positive evidence to support the hypothesis that one of its underappreciated causes is judicial independence. Part III then examines some normative consequences of this link between judicial independence and the regulative role of fault. In particular, I suggest that the account of remedial rationing offered here casts doubt on some central assumptions in Separation of Powers jurisprudence.

\section{FAULT AND THE RATIONING OF CONSTITUTIONAL REMEDIES}

This Part advances the descriptive claim that the Supreme Court has installed a requirement of fault as a threshold gatekeeping rule for constitutional remedies. This fault rule arose in the late 1970s and early 1980s. It diffused from constitutional tort law to postconviction habeas law and the rules governing the exclusionary rule as a remedy for Fourth and Fifth Amendment violations. It has also seeped into the substantive law in some domains. In its modal form, the faultbased gatekeeping rule observed across these domains requires that an individual litigant must demonstrate that the relevant constitutional violation was clear and unambiguous at the moment of the alleged violation in order to access either trial or a remedial order.

A fault rule of this kind emerged first from constitutional tort law under 42 U.S.C. $§ 1983$ and so-called Bivens suits; ${ }^{45}$ spread to the

\footnotetext{
doctrine and qualified immunity doctrine for the development of Fourth Amendment jurisprudence); Jennifer E. Laurin, Trawling for Herring: Lessons in Doctrinal Borrowing and Convergence, 111 Colum. L. REV. 670, 706 (2011) (suggesting the Court's impetus for "conceiving of the exclusionary rule as a remedy premised upon fault and desert" derives from constitutional tort doctrine).

45. See Bivens v. Six Unknown Named Agents of Fed. Bureau of Narcotics, 403 U.S. 388, 396-97 (1971). Under Bivens, the Court created a private cause of action for money damages against federal officials in their personal capacity who violate certain constitutional rules. Bivens involved a Fourth Amendment violation; the Court has subsequently been "circumspect" about extending the Bivens cause of action to other contexts. James E. Pfander \& David Baltmanis, Rethinking Bivens: Legitimacy and Constitutional Adjudication, 98 GEO. L.J. 117, 118 (2009).
} 
exclusionary rule in Fourth and (increasingly) Fifth Amendment contexts; and also to postconviction review of state and federal convictions. ${ }^{46}$ I should be explicit here that this list does not cover the waterfront of constitutional remedies. Indeed, I shall argue in Part II that the Court has conspicuously failed to extend the fault rule to other sorts of constitutional challenges. ${ }^{47}$ So my claim here is not that the Court has evinced blanket skepticism or hostility to constitutional remediation. Rather, I aim here to chart the domain in which the Court has erected barriers to some forms of relief-domains in which the demand for remediation is especially steep-while bracketing consideration of why that rule has not been extended further until Part II.

To analyze the regulative function of fault in constitutional remedies, I begin by briefly summarizing how the remedial mechanisms at issue evolved from, and superseded, a common-law framework of constitutional enforcement mechanisms. Unlike previous accounts, I underscore the migration of rationing rules from the familiar context of qualified immunity into not just some domains of constitutional law, but also parallel remedial mechanisms such as the exclusionary rule and postconviction habeas. ${ }^{48}$ Moreover, unlike previous recountings, my account deliberately underscores the fact that fault has become central not because of legislative choice, but rather as a consequence of unbounded judicial policy discretion. The fact that judges, rather than policymakers in the political branches, have been at the forefront in responding to the problem of remedial scarcity in constitutional law is central to the causal link between judicial independence and remedial rationing that I develop at length in Part II.

\section{A. The Remedial Dispensation for Individualized Constitutional Wrongs}

The current dispensation for constitutional remediation is of relatively recent vintage. From the Republic's founding until the early

46. See 28 U.S.C. $§ 2241$ (2012) (authorizing federal courts to grant habeas relief to prisoners); id. $\S \S 2254,2255$ (setting forth, respectively, rules for state prisoners and federal prisoners).

47. See infra Part II.B.

48. This is called "borrowing" by Nelson Tebbe and Robert L. Tsai, Constitutional Borrowing, 108 MICH. L. REV. 459, 463 (2010) (defining constitutional borrowing as "an interpretive practice characterized by a deliberate effort to bridge disparate constitutional fields for persuasive ends"). 
twentieth century, courts enforced constitutional rules largely via state-law tort and contract actions for damages into which federal-law elements could be injected. ${ }^{49}$ Even the federal government could be brought into constitutional compliance using a common-law action such as ejectment. ${ }^{50}$ Constitutional adjudication would typically arise in common-law contexts when a state defendant endeavored to deflect liability in pointing to a source of official authority and the plaintiff in response involved the Constitution to pierce that defense. ${ }^{51}$ In these early cases, the courts' role was limited to determining whether the conduct in litigation was lawful and then deciding whether "to award damages." ${ }^{, 52}$ It was then up to the legislature to determine whether to indemnify the defendant official. ${ }^{53}$

This common-law system of enforcement "dwindled" "over time for several interlocking reasons. First, state-law tort actions raising constitutional issues "by 'imperceptible steps' came to be seen as federal causes of action" by the end of the nineteenth century. ${ }^{55}$ Second, federal judges in the mid-1800s began to invoke with increasing frequency inchoate conceptions of immunity to deflect private suits against state actors, with the result that common-law damages actions for constitutional violations "atroph[ied]., ${ }^{, 56}$ Third,

49. Sina Kian, The Path of the Constitution: The Original System of Remedies, How it Changed, and How the Court Responded, 87 N.Y.U. L. REV. 132, 134 (2012) (noting that the Constitution was originally "to be implemented through remedies available for violations of common law rights"); Woolhandler, supra note 41, at 79-81.

50. Antonin Scalia, Sovereign Immunity and Nonstatutory Review of Federal Administrative Action: Some Conclusions from the Public-Lands Cases, 68 MICH. L. REV. 867, 882-86 (1970) (describing this practice).

51. Pfander \& Baltmanis, supra note 45, at 134 (noting that "for much of the nation's history, state common law provided victims with a right of action that . . could eventually result in the vindication of their constitutional rights" by treating the constitutional violation as "invalidat[ing] any authority conferred by federal law").

52. James E. Pfander \& Jonathan L. Hunt, Public Wrongs and Private Bills: Indemnification and Government Accountability in the Early Republic, 85 N.Y.U. L. REV. 1862, 1868 (2010); see also Bowden v. Morris, 3 F. Cas. 1032, 1032 (C.C.E.D. Va. 1876) (No. 1,715) ("Except in cases where property is taxed, or otherwise taken for public purposes, [government cannot deprive a person of rights without] suit in a court of justice.").

53. Pfander \& Hunt, supra note 52, at 1867 (noting that "reimbursement of a well-founded claim [was viewed] more as a matter of right than as a matter of legislative grace").

54. Kian, supra note 49, at 134.

55. Woolhandler, supra note 41, at 101.

56. Ann Woolhandler, Patterns of Official Immunity and Accountability, 37 CASE W. RES. L. REV. 396, 422-29, 450-51 (1987). For example, ejectment actions against the federal government, once common, came to seem eccentric, even impermissible. See, e.g., Malone v. Bowdoin, 369 U.S. 643, 648 (1962) (disallowing ejectment action against federal officer to recover real property in the absence of a claim that the officer's conduct violated the 
the post-Civil War economic boom led to a wave of regulation that in turn fed demand for property-right-like protections against unconstitutional state action that could not be satisfied via the traditional common-law forms. ${ }^{57}$ Finally, the common-law writ system itself fell into desuetude as simplified pleading, embodied in the 1934 Federal Rules of Civil Procedure, came to dominate judicial practice. $^{58}$

To fill the gap left by common-law actions, federal courts drew upon statutory causes of action and innovated to create new remedial pathways. This Part focuses on three remedial pathways, all of special relevance for vindicating individuals' constitutional rights against routine unconstitutional actions by line police officers, prosecutors, and bureaucrats. These three mechanisms are constitutional tort actions, postconviction habeas actions, and motions for the exclusion of unconstitutionally secured evidence in the course of a criminal investigation.

These remedies have important commonalities. Each targets a discrete official action usually focused on a particular individual, not a policy or statutory command, and seeks an individualized remedy (e.g., money, evidentiary suppression, or release). Each has roots in the late nineteenth century or early twentieth century, quickly fell into desuetude, and then did not see vigorous usage until the 1960s. ${ }^{59}$ Together, they comprised the remedial side of the Warren Court's aggressive campaign to install the Bill of Rights and rein in states' and localities' police, prosecutors, prison officials, and petty bureaucrats.

The Court's reconstruction of constitutional remedies had three prongs. First, the Court fashioned two constitutional tort remedies for use against state and federal actors. In 1961 the Court in Monroe v.

Constitution); Larson v. Domestic \& Foreign Commerce Corp., 337 U.S. 682, 687-88 (1949) (barring claim against federal officer to enjoin breach of contract).

57. Woolhandler, supra note 56 , at 452 ("[T]he change in the types of property that increasingly became the subject of government regulation may have been partly responsible for the modern dichotomy between damages and injunctive relief.").

58. See Act of June 19, 1934, Pub. L. No. 73-415, 48 Stat. 1064 (current version at 28 U.S.C. $\S 2072$ (2012)); Stephen N. Subrin, How Equity Conquered Common Law: The Federal Rules of Civil Procedure in Historical Perspective, 135 U. PA. L. REV. 909, 913 (1987) (exploring "the revolutionary character of the decision inherent in the Federal Rules to make equity procedure available for all cases").

59. Walter E. Dellinger, Of Rights and Remedies: The Constitution as a Sword, 85 HARV. L. REV. 1532, 1533 (1972) (commenting almost contemporaneously on the expansion in remedial resources in the individual rights context in this era). 
$\operatorname{Pape}^{60}$ revived a civil-damages remedy created by the Reconstructionera Ku Klux Klan Act. ${ }^{11}$ The provision, 42 U.S.C. $§ 1983$, allowed for money-damages actions against state actors that violated the Constitution. ${ }^{2}$ Until this date, $\S 1983$ had not been an effectual response to unconstitutional state action because courts had required that plaintiffs show state-law authorization for an alleged unconstitutional act. ${ }^{63}$ One study of $\S 1983$ 's first sixty-five years of enactment found only nineteen instances of the statute resulting in a reported decision. ${ }^{64}$ When courts did consider its effect, federal judges typically failed to impose any effectual remedial consequences. ${ }^{65}$ After Monroe had reinterpreted $\S 1983$ to reach both authorized and unauthorized actions of state officials the discrete, discretionary, and dispersed actions of state and municipal frontline officials became plausible subjects of judicial review for constitutional compliance. In the forty years after Monroe, the volume of constitutional damages actions filed pursuant to $\S 1983$ increased by two orders of magnitude. ${ }^{66}$ That growth was abetted by the Court's 1978 decision to expand government tort liability by permitting suits against municipalities where "the action is alleged to be unconstitutional implements or executes" a law or policy. ${ }^{67}$

Supplementing the Court's novel regulation of frontline state officials was a new willingness to review the constitutionality of discretionary decisions by federal officials interacting with citizens. Congress had enacted no civil action for constitutional torts actions against federal officials parallel to $\S 1983$. Nevertheless, the Court in 1971 inferred a damage remedy directly from the Constitution in Bivens v. Six Unknown Named Agents of Federal Bureau of

60. Monroe v. Pape, 365 U.S. 167 (1961).

61. Ku Klux Klan Act of Apr. 20, 1871, ch. 22, § 1, 17 Stat. 13 (current version at 42 U.S.C. $\S 1983$ (2012)).

62. Monroe, 365 U.S. at 172.

63. Id. (rejecting the then-dominant position that 42 U.S.C. $\S 1983$ allowed suit only when the alleged constitutional violation was authorized by state law).

64. Note, Limiting the Section 1983 Action in the Wake of Monroe v. Pape, 82 HARV. L. REV. 1486, 1486 n.4 (1969).

65. See, e.g., Hemsley v. Myers, 45 F. 283, 290 (C.C.D. Kan. 1891) (describing statute as purely “declaratory," creating no new rights or modes of proceeding).

66. Rudovsky, supra note 10, at 1208 (noting that the number of non-prisoner civil-rights suits increased from 150 in 1961 to 42,354 in 1998).

67. Monell v. N.Y. Dep't of Soc. Servs., 436 U.S. 658, 690 (1978) (ruling on a policy that compelled pregnant employees to take unpaid leaves of absence). 
Narcotics ${ }^{68}$ Notably, Bivens concerned the Fourth Amendment rights of a putative drug dealer during an FBI raid on his home ${ }^{69}$ - the same kind of routine, hard-to-observe official exercise of discretion that $\S 1983$ also distinctly addressed. Although the Supreme Court evinces persistent leeriness of expanding the availability of damages actions against federal officials in new contexts ${ }^{70}$ the Bivens remedy remains a hardy perennial in the lower courts. Recent empirical work suggests Bivens actions succeed between 17-34 percent of the time. ${ }^{71}$ Section 1983 and Bivens actions thus provide foundations for a robust body of constitutional torts jurisprudence.

The second expansion of constitutional remedies also occurred in 1961, when the Court in Mapp v. Ohio ${ }^{72}$ expanded the Fourth Amendment exclusionary rule remedy which had, until then, only availed defendants in federal courts ${ }^{73}$ to also cover prosecutions in state courts. ${ }^{74}$ Then, as now, it was state officials, not federal officials, who were tasked with the lion's share of policing. Incorporation of the exclusionary rule meant that that Court's 1949 incorporation of Fourth Amendment rights in Wolf v. Colorado ${ }^{75}$ had practical effect where previously it has been, in effect, a dead letter. ${ }^{76}$ Five years after imposing the exclusionary rule against the states in the Fourth Amendment context, the Court extended the exclusionary rule to the

68. Bivens v. Six Unknown Named Agents of Fed. Bureau of Narcotics, 403 U.S. 388, 39697 (1971) (recognizing cause of action for damages under Fourth Amendment).

69. For details about Webster Bivens and the search challenged in that case, see James E. Pfander, The Story of Bivens v. Six Unknown Named Agents of the Federal Bureau of Narcotics, in Federal COURTS STORIES 275, 275-77 (Vicki C. Jackson \& Judith Resnik eds., 2009).

70. See Pfander \& Baltmanis, supra note 45, at 118 (noting that the Court "has grown a good deal more circumspect" in extending Bivens to new doctrinal contexts).

71. Alexander A. Reinert, Measuring the Success of Bivens Litigation and Its Consequences for the Individual Liability Model, 62 STAN. L. REV. 809, 842-46 (2010).

72. Mapp v. Ohio, 367 U.S. 643 (1961).

73. Weeks v. United States, 232 U.S. 383, 389 (1914) (unanimously applying the exclusionary rule in federal prosecutions).

74. Mapp, 367 U.S. at 651 (describing the exclusionary rule as "part and parcel" of the Fourth Amendment). The Court has subsequently repudiated this account of the exclusionary rule. United States v. Calandra, 414 U.S. 338, 348 (1974).

75. Wolf v. Colorado, 338 U.S. 25 (1949).

76. Id. at 28 (incorporating the Fourth Amendment against the states). In Irvine v. California, 347 U.S. 128 (1954), in which the U.S. Supreme Court itself explicitly recommended a federal prosecution for criminal trespass against local officials who had violated the incorporated Fourth Amendment, no remedy was to be had. There was no investigation. The Department failed even to open a file on the matter. Morgan Cloud, Rights Without Remedies: The Court That Cried "Wolf," 77 Miss. L.J. 467, 492-97 (2007) (discussing Irvine). 
Fifth Amendment's prohibition against coerced testimony. In Miranda v. Arizona ${ }^{77}$ the Court installed a prophylactic regime of oral warnings in the police-interrogation context with enforcement again flowing through an exclusionary rule. ${ }^{78}$

Exclusionary rules in these contexts do not, strictly speaking, remedy the privacy, dignity, and security harms that the relevant constitutional provisions seek to prevent, but rather have been explained as vehicles for deterrence. ${ }^{79}$ To that extent, my terminology of "remedies" is imprecise. Nevertheless, not all remedies place litigants precisely in the position they would have been in absent a wrong occurring. ${ }^{80}$ Exclusion is fairly ranked as a remedy to the extent it is sought by a putatively injured party, and purports to eliminate an advantage that the state as counterparty possesses as a consequence of the constitutional wrong.

Finally-and roughly contemporaneously with these developments in constitutional tort law and the exclusionary rulethe midcentury Court also breathed new life into the writ of habeas corpus as a postconviction remedy for constitutional criminal procedure violations. For almost the first century of the Republic, the habeas writ was not available as a postconviction remedy. ${ }^{81}$ It was employed on rare occasions as a preemptive shield against criminal prosecution. $^{82}$ Only in 1867 did Congress expand the writ to encompass review of state convictions. ${ }^{83}$ The 1867 statute, though, was not followed by a expansion in habeas challenges. It was not until a series of four decisions starting in 1953 with Brown v. Allen ${ }^{84}$ that procedural constraints on habeas review withered. ${ }^{85}$ In the following

77. Miranda v. Arizona, 384 U.S. 436 (1966).

78. Id. at 447-48.

79. See, e.g., Akhil Reed Amar, Fourth Amendment First Principles, 107 HARV. L. REV. 757, 796 (1994).

80. Consider the persistent refusal of courts to give unforeseeable consequential damages for contract violations. See Hadley v. Baxendale, (1854) 156 Eng. Rep. 145 (Exch. Ct.).

81. Cf. Judiciary Act of 1789 , ch. $20, \S 14,1$ Stat. 73, 81-82 (not extending habeas to postconviction review).

82. See, e.g., Ex Parte Bollman, 8 U.S. (4 Cranch) 75, 95 (1807).

83. Habeas Corpus Act of 1867 , ch. $28, \S 1,14$ Stat. 385, 385-86.

84. Brown v. Allen, 344 U.S. 443 (1953).

85. NANCY J. KING \& JOSEPH L. HOFFMANN, HABEAS FOR THE TwENTY-FIRST Century: Uses, Abuses, AND THE Future OF THE GREAT Writ 56-57 (2011) (describing causes and size of shift in postconviction habeas filings). 
four decades, the volume of habeas litigation lodged by state prisoners engorged even more dramatically than $§ 1983$ filings. ${ }^{86}$

It is important to reiterate here that the three remedies identified here do not cover the waterfront of potential judicial mechanisms for enforcing the Constitution. Indeed, an important element of Part II's argument will focus on how exceptions to the fault rule create incentives over the kind of constitutional suits litigants file. To anticipate that discussion, it is worth noting here the two most important alternatives to damages-exclusion and habeas relief-are vehicles for individuals to secure some judicial response for a constitutional wrong.

First, at least since the 1907 decision in Ex Parte Young, ${ }^{87}$ federal courts have issued injunctions against state officials barring them from civil or criminal enforcement of a state law when enforcement will violate the constitutional rights of the plaintiff. ${ }^{88}$ Today, plaintiffs invoking Young can allege an ongoing violation of federal law and obtain prospective relief without regard to state sovereign immunity. ${ }^{89}$ Second, in 1934, Congress enacted the federal Declaratory Judgment Act, ${ }^{90}$ pursuant to which plaintiffs could secure relief against state actors even when an injunction could not be obtained. ${ }^{91}$ Injunctive or

86. Id. at 60 . The rise in habeas filings is likely a consequence of the dramatic expansion in incarceration that characterizes federal and state criminal justice policy since the beginning of the 1970s. See generally BRUCE WESTERN, PUNISHMENT AND INEQUALITY IN AMERICA 12-15 (2006). The rise of mass incarceration also led to a sharp rise in the volume of prisoner litigation. Margo Schlanger, Inmate Litigation, 116 HARV. L. REV. 1555, 1578-87 (2003) (documenting evidence).

87. Ex Parte Young, 209 U.S. 123 (1908).

88. The pivotal case is Ex Parte Young, 209 U.S. at 148 (authorizing injunction against unconstitutional state action absent specific statutory authorization for that remedy), but federal courts issued injunctions against unconstitutional state action long before Young. See Edwin M. Borchard, Government Liability in Tort, 34 YALE L.J. 1, 19 n.70 (1924) (collecting cases dating from 1838).

89. Va. Office for Prot. \& Advocacy v. Stewart, 131 S. Ct. 1632, 1639 (2011); accord Verizon Md. Inc. v. Pub. Serv. Comm'n of Md., 535 U.S. 635, 645 (2002). Congress, however, can foreclose a Young injunctive remedy by enacting a sufficiently specific statutory scheme. Seminole Tribe of Fla. v. Florida, 517 U.S. 44, 73-76 (1996). Further, Young cannot be used to obtain funds from a state's treasury, or order specific performance of a State's contract. See Edelman v. Jordan, 415 U.S. 651, 666 (1974) (recognizing that Young does not allow relief against a state officer); In re Ayers, 123 U.S. 443, 502 (1887) ("A bill in equity for the specific performance of the contract against the state by name, it is admitted could not be brought.").

90. Act of June 14, 1934, ch. 512, 48 Stat. 955.

91. Steffel v. Thompson, 415 U.S. 452,459 (1974) (holding that declaratory relief was available even though the threatened state criminal prosecution could not be enjoined). For an argument that the gap between injunctive and declaratory relief is elusive, see Samuel L. Bray, The Myth of the Mild Declaratory Judgment, 63 DUKE L.J. 1091, 1095 (2014). 
declaratory relief is of limited utility in many instances. When a constitutional violation is inflicted without prior notice, and where the damage is immediately realized-as is often the case when police, prosecutors, and bureaucrats are concerned-then neither an injunction nor a declaratory judgment will be of great use. In such cases, the vindication of individual constitutional rights will generally hinge on whether an individual litigant can avail themselves of a constitutional tort action, a suppression motion, or a postconviction remedy. Absent these tools, a constitutional violation will have no legal or practical consequence.

\section{B. Fault in Constitutional Tort Law}

But when do plaintiffs have access to remedies such as damages, suppression, or habeas relief? Since the mid-1970s, the Court has rationed the availability of each of these three remedies by installing a threshold requirement that individual rights claimants must typically demonstrate that an offending state official not only violated the Constitution, but did so in an especially flagrant and obvious way. That is, it is often no longer sufficient to allege a violation of the Constitution. It is also necessary to allege that the violation of the Constitution was especially clear and unambiguous so as to warrant the expense of trial and the imposition of liability. The Court has framed this threshold requirement as one of "fault" or "culpability.", Although the latter term can be used to mark out the distinctive aspect of conduct warranting criminal, but not civil penalties, ${ }^{93} \mathrm{I}$ nonetheless follow the Court's usage of the imprecise term "fault." To emphasize, I use that term solely to identify conduct in which the constitutional violation is unambiguously clear ex ante, and not to gesture toward an inchoate notion of moral blameworthiness. That is, the term fault in this context does not pick out any facts about the defendant's state of mind. ${ }^{94}$

92. Bd. of Cnty. Comm'rs v. Brown, 520 U.S. 397, 404-05 (1997) (using the terms "fault" and "culpability" almost interchangeably); see also City of Canton v. Harris, 489 U.S. 378, 392 (1989) (requiring "deliberate indifference" to constitutional rights).

93. Issachar Rosen-Zvi \& Talia Fisher, Overcoming Procedural Boundaries, 94 VA. L. REV. 79, 94 (2008) (noting that "moral culpability" characterizes criminal conduct, but not conduct to which civil penalties attach).

94. The Court, that is, could plausibly (and with some gain in accuracy) have used a term such as "unreasonable fault," but it did not, and to innovate in terminology here would be confusing. 
The move toward fault is clearest in the constitutional tort context, and it is there I start. Within this doctrinal domain, fault is a familiar element of qualified immunity doctrine, but it also plays a central regulative role in municipal liability doctrine, and even in the substantive law defining some of the constitutional torts most commonly enforced through $\S 1983$ and Bivens actions. But conventional accounts of this doctrine miss two points that I stress in the following account of qualified immunity and cognate fault rules in constitutional tort law. First, the fault role stands on no legislative foundation, but is rather a function of relatively freewheeling judicial policymaking discretion. Second, although notionally explained as a way of making officials' tasks easier, the fault rule in constitutional tort serves also to mitigate pressure upon judicial effort and resources.

1. Fault as the Operative Principle of Qualified Immunity. No federal statute creates immunity from tort liability in officer suits pursuant to $\S 1983$ or Bivens. Rather, official immunity is the Justices' creation. This is most clearly evident in the incremental fashion it has emerged, a pathway that bears the clear fingerprints of conscious judicial policymaking, rather than any fidelity to legislative intent. ${ }^{95}$ Initially, qualified immunity was modest in theory and effect. The Court in the 1967 case of Pierson v. Ray ${ }^{96}$ first granted immunity to officers acting pursuant to a state statute later held unconstitutional on the ground that such immunity was a "settled principle of law" that Congress had not meant to abolish when enacting the Ku Klux Klan Act. ${ }^{97}$ Both Pierson's holding and its reasoning were circumscribed. First, only official actions taken "in good faith," and, with respect to police, on the basis of "probable cause" secured an exception from liability. ${ }^{98}$ That is, the ex ante existence of some positive legal authority for an official act seemed key to immunity. Second, the Court recognized only such immunity as existed at common law, and then only because it presumed that Congress did

95. See Alan K. Chen, The Facts About Qualified Immunity, 55 EMORY L.J. 229, 233-61 (2006) (providing a chronological account of the development of immunity doctrines).

96. Pierson v. Ray, 386 U.S. 547 (1967).

97. Id. at 553-54 (noting that "Congress would have specifically so provided had it wished to abolish" qualified immunity for police officers); accord Tenney v. Brandhove, 341 U.S. 367, 379 (1951).

98. Pierson, 386 U.S. at 555. 
not lightly unsettle "solidly established" common-law principles. Legislative intent, therefore, was the touchstone of Pierson's analysis.

In 1975, the Court in Wood v. Strickland ${ }^{100}$ began to modify the theoretical foundations, if not the scope, of immunity. Such immunity, explained the Wood Court, applied so long as officers act in good faith without malicious intent, and neither reasonably know, nor reasonably should have known, of its illegality. ${ }^{101}$ Wood did not move far from Pierson's focus on the existence of positive legal authority. Yet rather than locating its immunity rule in the common law, the Court looked directly to "strong public-policy" considerations for its justification. ${ }^{102}$ In particular, the Wood Court conjured the concern that "even the most conscientious... decisionmaker [would be deterred] from exercising his judgment independently, forcefully, and in a manner best serving the long-term interest of the [state] school and the students." 103

Subsequent immunity opinions acknowledged Pierson's foundation in background tort rules defeasible only by clear congressional statement. ${ }^{104}$ But the Court's later expansions of qualified immunity rapidly came unmoored from Pierson's historical anchorage. The doctrine instead gained momentum from the express invocation of policy considerations. The result was a shift in immunity's breadth: Where Pierson intimated that immunity availed if the official could point to the existence of a positive source of plausible authority for a challenged act, later cases took as a touchstone the absence of a prohibitory source of law. This pivot dramatically engorged immunity's reach, albeit without any clear normative justification from the Court.

Seven years later, the Court invoked the same deterrence-related policy concern, but in so doing expanded the substantive reach of qualified immunity. In Harlow v. Fitzgerald, ${ }^{105}$ the Court invoked

99. Id. at 553-54.

100. Wood v. Strickland, 420 U.S. 308 (1975).

101. See id. at 322 .

102. Id. at 318; Butz v. Economou, 438 U.S. 478, 506-07 (1978) (relying on "considerations of public policy" to delimit qualified immunity). For an earlier recognition of the public policy foundations of qualified immunity doctrine, see Spalding v. Vilas, 161 U.S. 483, 498 (1896).

103. Wood, 420 U.S. at 319-21 ("[T]here must be a degree of immunity if the work of the [state institution] is to go forward ....").

104. Hence, the Court has relied on common-law principles to extend absolute immunity to prosecutors, see Imbler v. Pachtman 424 U.S. 409, 419 (1976), and also to permit punitive damages, see Smith v. Wade, 461 U.S. 30, 34 (1983).

105. Harlow v. Fitzgerald, 457 U.S. 800 (1982). 
again deterrence-related public policy considerations, but abandoned Wood's subjective good-faith requirement. ${ }^{106}$ The Harlow Court instead shielded officials from liability unless their conduct "violate[d] clearly established statutory or constitutional rights of which a reasonable person would have known." ${ }^{107}$ That is, immunity would attach in the absence of a clear prohibition-rather than (as in Pierson) in the presence of a clear authorization. In a subsequent case, the Court further refined the Harlow test by insisting that it would be applied to allegations in the most "particularized" sense possible, that is, that the illegality of an alleged constitutional violation must be starkly "apparent" to the defendant. ${ }^{108}$ Today, the Court characterizes qualified immunity as protecting "all but the plainly incompetent or those who knowingly violate the law," and not merely those who (as in Pierson) reasonably rely on the constitutionality of a prior statutory enactment. ${ }^{109}$ As far as money damages are concerned, the Constitution is a hazard only for the blunderer and the fool. ${ }^{110}$

In comparison to its antecedent in Pierson, the current iteration of qualified immunity has two important qualities. First, since Wood, the Court has made no pretense of mining the common law or legislative intent for direction, but has engaged in naked policymaking. The demand for particularity, for example, is grounded solely on first-order consequentialist analysis of tort's feedback effect on official action. ${ }^{111}$ Second, notwithstanding the pragmatic foundation of the doctrine, the proffered justifications for qualified immunity do not well explain its actual scope. The Court has repeatedly expressed alarm about tort's potential chilling effect on

106. Id. at 818 .

107. Id.; see also Procunier v. Navarette, 434 U.S. 555, 565 (1978) (anticipating the rule in Harlow).

108. Anderson v. Creighton, 483 U.S. 635, 640 (1987); accord Plumhoff v. Rickard, 134 S. Ct. 2012, 2023 (2014). The effect of qualified immunity will therefore be greatest when the Court relies on standards rather than rules. Application of the former rarely requires a new rule, United States v. Chaidez, 133 S. Ct. 1103, 1107-08 (2013), in a way that would satisfy Anderson's particularity requirement.

109. Ashcroft v. al-Kidd, 131 S. Ct. 2074, 2085 (2011) (quoting Malloy v. Riggs, 475 U.S. 335, $341(1985))$.

110. Sounding an even more alarmist note, Chen argues that the Court has conflated qualified immunity with absolute immunity. Chen, supra note 95, at 275.

111. See Anderson, 483 U.S. at 643 ("An immunity that has as many variants as there are modes of official action and types of rights would not give conscientious officials that assurance of protection that it is the object of the doctrine to provide."). The Anderson Court does not cite or discuss any common-law antecedents for its rule. 
official action. ${ }^{112}$ But the Court has never explained how that overdeterrence rationale motivates the move from Pierson's demand for positive law to Harlow's search for a clear prohibition. Worse, the Court has never offered any empirical evidence that overdeterrence is in fact a problem. Recent empirical work on indemnification of tort actions in the policing context confirms that, at least in that context, indemnification is "virtually always" available, ${ }^{113}$ even when the officer in question has violated both the Constitution and relevant criminal law. ${ }^{114}$ Indeed, many jurisdictions do not even have a mechanism to transmit information gained through lawsuits to police departments that employ serial rights offenders. ${ }^{115}$ Although this data has only become available recently, earlier studies reached substantially parallel results. ${ }^{116}$ Both recent and older studies hence suggest that it has never been the case that individual officials are likely to pay from their own pockets. This means not only that the Court's overdeterrence argument based on the direct effect of money damages is not persuasive as a matter of fact. ${ }^{117}$ It also means that the central element of the qualified immunity edifice was one asserted without foundation by the government, and accepted on the basis of mere governmental ipse dixit by the Court. The Court has built a comprehensive, transubstantive doctrinal framework for limiting constitutional remedies without ever asking whether its basic empirical predicate held true.

112. See supra note 103 and accompanying text.

113. Joanna C. Schwartz, Police Indemnification, 89 N.Y.U. L. REV. 885, 890 (2014) ("Between 2006 and 2011, in forty-four of the country's largest jurisdictions, officers financially contributed to settlements and judgments in just .41\% of the approximately 9,225 civil rights damages actions resolved in plaintiffs' favor, and their contributions amounted to just $.02 \%$ of the over $\$ 730$ million spent by cities, counties, and states in these cases.”).

114. Id. at 923-95.

115. See Joanna C. Schwartz, Myths and Mechanics of Deterrence: The Role of Lawsuits in Law Enforcement Decisionmaking, 57 UCLA L. REV. 1023, 1028-30 (2010) (finding that law enforcement agencies rarely gather and analyze information from lawsuits brought against them and their officers).

116. See, e.g., Lant B. Davis et al., Project, Suing the Police in Federal Court, 88 YALE L.J. 781, 810-12 (1979) (reporting government defense and indemnification of police officers in Connecticut); Theodore Eisenberg \& Stewart Schwab, The Reality of Constitutional Tort Litigation, 72 CORNELl L. REV. 641, 686 (1987) (finding no cases in which "an individual official had borne the cost of an adverse constitutional tort judgment").

117. Qualified immunity might be defended based on officials' risk aversion arising from the prospect of adverse career consequences, selection effects, and the distribution of political costs. Jeffries, Disaggregating, supra note 15, at 267-68. But even advocates of these arguments concede that they rest on "fundamentally speculative" empirical grounds. Id. at 268. 
Even if the reason the Court gives for its currently robust iteration of qualified immunity fails, there is an obvious alternative. Qualified immunity is "an immunity from suit rather than a mere defense to liability." "It is designed to "permit the defeat of insubstantial claims without resort to trial." ${ }^{, 19}$ So powerful is this preference for pretrial resolution of constitutional tort claims that the Court has crafted a textual exception to the general prohibition on interlocutory appeals when qualified immunity is denied. ${ }^{120}$ Qualified immunity therefore does not merely economize on the litigation expenses of public officials, it also rations out judicial resources with increasing care. $^{121}$ And whereas the overdeterrence-related justification for qualified immunity rests on elusive, and perhaps false, empirical supposition, the judicial-economy justification for qualified immunity is both immediately clear and obviously true.

2. Fault's Spillovers from Constitutional Tort Doctrine. The fault rule embedded in today's qualified immunity law has leaked from its original locus in constitutional tort doctrine into three contexts where the Court's overdeterrence concern plainly does not apply. These spillovers further undermine the conclusion that deterrence concerns explain the domain of tort-related fault.

First, at least formally, the protections of qualified immunity do not apply to tort actions against municipalities. ${ }^{122}$ Nevertheless, current doctrine requires a showing that a municipal defendant not only violated a constitutional rule, but affirmatively chose to ignore a clear constitutional prohibition. In Board of County Commissioners $v$. Brown, ${ }^{123}$ the Court stated, without explanation or elaboration, that "rigorous standards of culpability and causation must be applied to municipal liability cases." 124 This demand has had the greatest practical force in cases alleging municipal liability based on improper

118. Pearson v. Callahan, 555 U.S. 223, 231 (2009) (quoting Mitchell v. Forsyth, 472 U.S. $511,526(1985))$.

119. Harlow v. Fitzgerald, 457 U.S. 800, 819 (1982); accord Behrens v. Pelletier, 516 U.S. 299, 305-06 (1996).

120. See Mitchell v. Forsyth, 472 U.S. 511, 530 (1985) (extending government officers a right to interlocutory appellate review of decisions that reject a qualified immunity defense).

121. It is worth noting that the Court has not required state courts to follow Mitchell's exception from the rule against interlocutory appeals. See Johnson v. Frankell, 520 U.S. 911, 913 (1997).

122. Owen v. City of Independence, 445 U.S. 622, 624-25 (1980).

123. Bd. of Cnty. Comm'rs v. Brown, 520 U.S. 390 (1997).

124. Id. at 397 (emphasis added). 
training or supervision. Such liability can be established only by showing a constitutional deficiency was "so obvious, and the inadequacy so likely to result in the violation of constitutional rights" that policymakers could be said to be "deliberately indifferent." 125 That is, it extended the fault role (understood once more not as a demand for blameworthiness but rather a gross form of constitutional error) to facilitate threshold dismissal.

For example, rejecting a recent suit challenging repeated prosecutorial misconduct in New Orleans, the Court set aside a jury finding of liability because the plaintiff had failed to show "[p]olicymakers' continued adherence to an approach that they know or should know has failed to prevent tortious conduct," notwithstanding a string of cases in which state courts had reversed convictions based on the state's misconduct. ${ }^{126}$ As the dissent noted, the trial record in that case evinced "the conceded, long-concealed prosecutorial transgressions were neither isolated nor atypical., ${ }^{, 27}$ In practice, this ruling means that moving a municipal liability claim from the pretrial stage to plenary courtroom proceeding requires strong threshold evidence of a persistent pattern of unconstitutional conduct amounting to intentional violation of the Constitutionevidence that, in the majority of cases, will in practice be unavailable to most plaintiffs without discovery.

Notwithstanding its rigorous enforcement of the fault rule in the municipal liability context, the Court has not explained why there is a need to avoid overdeterrence in such cases. Unlike individual officials, municipalities are comparatively well placed to internalize both the costs and benefits of constitutional violations, and thus not err on the side of excessive precaution. ${ }^{128}$ The current doctrine's structure, by contrast, means that municipal entities will systematically fail to internalize the costs of unconstitutional actions. At the very least, there is some reason to think that municipal liability

125. City of Canton v. Harris, 489 U.S. 378, 390 (1989); see also St. Louis v. Praprotnik, 485 U.S. 112, 124-27 (1988) (establishing a narrow definition of official policymakers for $\S 1983$ purposes).

126. Connick v. Thompson, 131 S. Ct. 1350, 1360 (2011).

127. Id. at 1370 (Ginsburg, J., dissenting).

128. Peter Schuck has argued that qualified immunity is warranted because officials do not internalize the upside gains from legally risky actions, and hence should not be required to internalize their costs in order to avoid asymmetries in their incentive structures. PETER H. SCHUCK, SUING GOVERNMENT: CITIZEN REMEDIES FOR OFFICIAL WRONGS 59-81 (1983); see also Jeffries, Disaggregating, supra note 15, at 265-70. 
should be more expansively available than individual officer liability if the focal concern is overdeterrence. ${ }^{129}$ The Court, in short, has not even tried to explain - and may not be able to explain - its extension of fault from the individual to the municipal liability context based on deterrence concerns. That extension, though, may alternatively fit an account pivoted on the need to titrate carefully judicial resources in a world where municipalities persistently violate the Constitution.

Second, the Court has extended the fault rule from qualified immunity to challenges to unconstitutional taxes. Ex post remedies for an invalid tax are available only when "legislators would have good reason to suppose that enactment of the ...tax would... violate their oath to uphold the United States Constitution." However this opaque judicial gloss is understood, a "good reason" standard extends the fault-based framework familiar from qualified immunity to a tax context in which concerns about overdeterrence are weak. Legislators responsible for taxation have staff, including lawyers, capable of sophisticated legal and constitutional analysis. It might be thought that doctrinal rules should incentivize a high degree of care among such legislators, rather than subsidizing carelessness. Moreover, in practice, this standard means states can throw up impediments that complicate challenges to unconstitutional taxes, often rendering many such challenges futile. ${ }^{131}$ If the justification for a fault-based safe harbor is the husbanding of judicial resources, by contrast, this extension of qualified immunity may seem more sensible.

Third, starting in the early 1980s, the Court has fashioned a set of rules to limit constitutional tort actions for state deprivations of liberty and property interests in the absence of intentional or systemic state actions. ${ }^{132}$ In 1981, the Court imposed an exhaustion rule for tort suits based on a state official's discretionary act depriving a person of property - a charge most common in the policing and incarceration

129. For a development of this point, see Jack M. Beermann, Municipal Responsibility for Constitutional Torts, 48 DEPAUL L. REV. 627, 646 (1999).

130. Am. Trucking Ass'ns v. Smith, 496 U.S. 167, 182 (1990) (plurality opinion) (O'Connor, J.).

131. See Amy Silverstein, The Rewards and Frustrations of Successful Constitutional Challenges to State Taxes, 87 J. TAX'N 102, 102 (1997) (noting that "success on the merits does not always result in a refund of the unconstitutional taxes," and listing a variety of grounds upon which refunds have been denied).

132. For a summary of this jurisprudence, see Richard H. Fallon, Jr., Some Confusions About Due Process, Judicial Review, and Constitutional Remedies, 93 COLUM. L. REV. 309, 34552 (1993). 
contexts. ${ }^{133}$ In the 1986 Daniels v. Williams ${ }^{134}$ decision, for example, the Court held that merely negligent acts do not amount to a deprivation under the Due Process Clause. ${ }^{135}$ Like qualified immunity doctrine, Daniels and its progeny require an allegation that a defendant official has traduced an especially obvious and unambiguous constitutional rule to move past a threshold motion to dismiss to get to trial and potential liability. Mere negligence that extinguishes a life or destroys property yields no cause for remediation. ${ }^{136}$ That rule, though, applies only to "random and unauthorized" deprivations of liberty or property, which cannot be challenged until state remedies have been exhausted, but not in challenges to systematic policies that result in constitutional deprivations. ${ }^{137}$ That is, they apply precisely when the volume of suits demanding relief is likely to be greatest.

This is also one of the rare instances in which one need not guess at the Court's attention to its own institutional concerns. They are explicit on the surface of its opinions. The Court has repeatedly announced that $\S 1983$ should not become a "font of tort law to be superimposed upon whatever systems may already be administered by the States." ${ }^{138}$ The concern with federal caseload managementeven at the cost of allowing a tranche of constitutional violations to

133. Parratt v. Taylor, 451 U.S. 527, 543-44 (1981) (holding that no due process deprivation has occurred if the state provides adequate postdeprivation process to remedy random, unauthorized acts of state officers), overruled in part by Daniels v. Williams, 474 U.S. 327 (1986); see also Hudson v. Palmer, 468 U.S. 517, 533 (1984) (extending Parratt's exhaustion principle to intentional torts).

134. Daniels v. Williams, 474 U.S. 327 (1986).

135. Id. at 329-30.

136. See Cnty. of Sacramento v. Lewis, 523 U.S. 833, 848-49 (1998) ("We have accordingly rejected the lowest common denominator of customary tort liability as any mark of sufficiently shocking conduct, and have held that the Constitution does not guarantee due care on the part of state officials; liability for negligently inflicted harm is categorically beneath the threshold of constitutional due process."). In practice, this means that rights holders, especially in comprehensively regulated environments (such as prisons, public housing, and the like) will have no federal remedy for a constitutional violation unless they can point to intent. Given the pervasive asymmetries in power and information between the public and the state in these contexts, it will often be the case that potential plaintiffs will have no intent evidence.

137. See Zinermon v. Burch, 494 U.S. 113, 137-38 (1990) (holding that Parratt does not apply when the deprivation was foreseeable and authorized-as distinct from random and unauthorized-and when predeprivation process would have been feasible); see also Logan v. Zimmerman Brush Co., 455 U.S. 422, 436-37 (1982) (holding that postdeprivation remedies do not satisfy due process where deprivation is caused by established state procedures).

138. See, e.g., Paul v. Davis, 424 U.S. 693, 701 (1976); Fallon, supra note 132, at 339 (noting and discussing repeated invocation of this concern). 
pass without any effectual remedy, at least from a federal court-is visible on the surface. Moreover, it is presented without any effort to explain why the class of plaintiffs thereby deprived of a remedy are otherwise undeserving. Fault's penumbral extensions in the constitutional tort context to municipal liability suits, challenges to unconstitutional state taxes, and random, unauthorized liberty or property deprivations therefore are not well explained by the motives evinced in Harlow and subsequent qualified immunity cases.

\section{Fault and the Exclusionary Rule}

Fault has also leaked from the constitutional tort context to the exclusionary rule context in the Fourth Amendment context and, increasingly, in the Fifth Amendment context. The trajectory of fault as a threshold constraint on suppression remedy evinces several commonalities with analogous doctrine in the constitutional tort context. First, while initially glossed as a remedy for overdeterrence, its applications quickly outpaced that justification. Second, it too has leaked into the substance of the Fourth Amendment. Finally, there is some threshold circumstantial evidence that judicial interests, rather than officials' interests, better explain the doctrine's development.

Unlike the issuance of damages pursuant to $\S 1983$, the exercise of judicial power that comprises the exclusionary rule lacks a clear statutory foundation. Moreover, since 1974, when the Court characterized it as a discretionary mode of Fourth Amendment enforcement, its constitutional basis has been at least contestable. ${ }^{139}$ For a decade thereafter, the Mapp rule nevertheless endured roughly unscathed. Its doctrinal retrenchment began not at a litigant's behest, but at the Court's. It was the Court that sua sponte ordered reargument in 1983 in Illinois v. Gates ${ }^{140}$ to determine whether Mapp should be modified "not to require the exclusion of evidence obtained in the reasonable belief that the search and seizure at issue was consistent with the Fourth Amendment." ${ }^{, 141}$ Although the Court did not reach this issue in Gates, Justice White's concurrence invoked the recently decided Harlow v. Fitzgerald opinion as a guide to narrowing

139. See United States v. Calandra, 414 U.S. 338, 348 (1974) (describing the exclusionary rule as a judicially created remedy).

140. Illinois v. Gates, 462 U.S. 213 (1983).

141. Petitioner's Brief on Reargument at i, Gates, 462 U.S. 213 (No. 81-430), 1983 WL 482675 (citations omitted). 
Mapp. ${ }^{142}$ Beyond touting the benefits of a fault-based safe harbor for effective law enforcement, Justice White also drew attention to the rule's payoff to the judiciary in terms of a "reduction in the number of cases which will require elongated considerations of the probable cause question." ${ }^{143}$ Concerns of judicial economy, in short, were in plain view even before the fault rule was installed into the structure of exclusionary rule jurisprudence.

A year later, Justice White would write for the Court in United States v. Leon ${ }^{144}$ and fashion a "good-faith" exception for searches in reliance upon warrants not supported by probable cause. ${ }^{145}$ The Leon Court once more cited qualified immunity precedent, intimating thereby that the exclusionary rule would not apply absent intentional or recklessly negligent action. ${ }^{146}$ Consistent with these citations, Leon then deployed the concern with excess deterrence familiar from Harlow, asserting that a magistrate who issued a warrant based on an erroneous probable-cause determination lacked any "stake in the outcome of particular criminal prosecutions" and consequently would not be affected by subsequent suppression. ${ }^{147}$ Completing the circle, Justice Stevens would later observe that the Leon standard would in turn influence the Court's approach to the level of specificity at which a qualified immunity analysis would be pitched. ${ }^{148}$

The Leon exception was at first limited to cases in which the issuing magistrate had erred, and an officer had reasonably relied on her decision. Subsequent cases extended Leon to cases where police officers errantly relied on subsequently invalidated criminal statutes ${ }^{149}$ or later-overruled Supreme Court precedent, ${ }^{150}$ and also where a

142. Gates, 462 U.S. at 266-67 (White, J., concurring).

143. Id. at 267.

144. United States v. Leon, 468 U.S. 897 (1984).

145. Id. at $920-22$.

146. See id. at $922 \& \mathrm{n} .23$ (stating that "the officer's reliance on the magistrate's probablecause determination and on the technical sufficiency of the warrant he issues must be objectively reasonable"); see also Laurin, supra note 44, at 703-04 (discussing doctrinal migration in Leon).

147. Leon, 468 U.S. at 917 ("Judges and magistrates are not adjuncts to the law enforcement team; as neutral judicial officers, they have no stake in the outcome of particular criminal prosecutions. The threat of exclusion thus cannot be expected significantly to deter them."); see also Messerschmidt v. Millender, 132 S. Ct. 1235, 1246-47 (2012) (exploring Leon's deterrencebased logic).

148. Anderson v. Creighton, 483 U.S. 635, 659 (1987) (Stevens, J., dissenting) (noting the migration of Leon's "double standard" to the qualified immunity context).

149. Illinois v. Krull, 480 U.S. 340, 349-50 (1987).

150. Davis v. United States, 131 S. Ct. 2419, 2428-29 (2011). 
warrant was issued as a result of errors by a court administrator ${ }^{151}$ or an administrator within the police department itself. ${ }^{152}$ In recent cases, the Court has come close to generalizing Leon into a widely applicable barrier to suppression on Fourth Amendment grounds absent "deliberate, reckless, or grossly negligent conduct" or "recurring or systematic negligence." 153 A deterrence-based line of reasoning in the context of policing and criminal trials has led the Court to roughly the same threshold fault gatekeeping rule as the "policy" considerations invoked in the distinct constitutional tort context. $^{154}$ Just as in the tort context, ${ }^{155}$ moreover, a fault-based gatekeeping rule for suppression creates a category of cases in which a person has neither an ex ante opportunity to challenge a government action, nor any ex post remedy for a constitutional violation. $^{156}$

151. Arizona v. Evans, 514 U.S. 1, 14-15 (1995).

152. Herring v. United States, 555 U.S. 135, 140 (2009); see also Davis, 131 S. Ct. at 2427 (stating that "[w]hen the police exhibit 'deliberate,' 'reckless,' or 'grossly negligent' disregard for Fourth Amendment rights, [then] the deterrent value of exclusion is strong").

153. Herring, 555 U.S. at 144. Herring's formulation was anticipated by Franks v. Delaware, which held that criminal defendants could invalidate a warrant based on flaws in the underlying affidavits only in cases of "deliberate falsehood" or "reckless disregard of the truth." Franks v. Delaware, 438 U.S. 154, 171 (1978).

154. The analogy between the two lines of cases was anticipated in Richard A. Posner, Excessive Sanctions for Governmental Misconduct in Criminal Cases, 57 WASH. L. REV. 635, 638-40 (1982), which argues that both exclusion of evidence and officer liability for Fourth Amendment violations risk overdeterrence of legitimate law enforcement activity. Although this deterrence argument is not the object of my analysis here, it is worth noting a certain confusion in the argument Posner offers. Posner's analysis assumes that there is a social welfare function that assigns no particular value to constitutional rights. But it is not clear why this should be so. To the contrary, one way of understanding a constitution is as a statement of the particular forms of human welfare that are of special concern to the polity. To assign no particular weight to constitutional violations, as Posner's analysis does, is to fail to apply the salient social-welfare function for our society. The verbal formulations of the concern differs, although the substantive concern is identical: in the tort context, the Court expresses concerns about deterring beneficial action; in the exclusionary rule context, the Court finds no need to deter unconstitutional actions.

155. Cf. David Rudovsky, The Qualified Immunity Doctrine in the Supreme Court: Judicial Activism and the Restriction of Constitutional Rights, 138 U. PA. L. REV. 23, 53 (1989) (noting that qualified immunity often leaves "an official's conduct ... governed by the subconstitutional immunity standard ... [and] without a clear guide for future conduct").

156. See Donald Dripps, Living with Leon, 95 YALE L.J. 906, 907 (1986) (noting that "the Leon majority has withdrawn that remedy in a class of cases for which no other remedy is available"). As a practical matter, criminal defendants will have no cost-effective damages remedy for knock-and-announce violations and many other searches that generate inculpatory evidence. 
One other extension of Leon merits elaboration here. The Court's focus on overdeterrence suggests that its fault gatekeeping rule should not be extended to intentional Fourth Amendment violations or the substance of Fourth Amendment law. As in the constitutional tort context, however, fault has seeped out from the domain in which its notional deterrence-related justifications apply to domains in which its justification does not obtain. In Hudson $v$. Michigan,${ }^{157}$ the Court held that the exclusionary rule was inapplicable to violations of the "knock-and-announce" rule ${ }^{158}$ for executing warrants on the ground that the interests protected by the knock-andannounce rule were causally unrelated to the likelihood that evidence would be discovered. ${ }^{159}$ In addition to leaning on the (obviously flawed) logic that suppression would fail to create an incentive for police to comply with a constitutionally compelled rule, the Hudson Court fell back on the assertion that the "increasing professionalism of police forces" meant exclusion was no longer necessary. ${ }^{160}$ The force of this argument is hard to discern: even if police are professionalized, this does not mean that they will necessarily follow a constitutional rule that can by law be violated without consequences. To the contrary, as Professor David Sklansky has noted, when California amended its state constitution to provide that garbage searches were unconstitutional but that no exclusionary rule applied, police were "trained to ignore" that constitutional rule, and instead conduct illegal garbage searches. ${ }^{161}$ Professionalism simply increased the alacrity with which unconstitutional practices diffused across police departments. To assume, as the Hudson Court seems to, that professionalism correlates with diminished rates of constitutional violation is not obviously justified.

In 2015, the Court extended the fault rule from the remedies context to substantive Fourth Amendment law, tracking the remedies-to-substance spillover observed in constitutional tort law. ${ }^{162}$ Again, the deterrence rationale for this migration is hard to discern.

157. Hudson v. Michigan, 547 U.S. 586 (2006).

158. See Wilson v. Arkansas, 514 U.S. 927, 931-32 (1995) (imposing knock-and-announce rule for warrant executions).

159. Hudson, 547 U.S. at 594.

160. Id. at 598 .

161. David Alan Sklansky, Is the Exclusionary Rule Obsolete?, 5 OHIO ST. J. CRIM. L. 567, 580-81 \& n.70 (2008) (citation omitted).

162. See supra Part I.B.2. 
In Heien v. North Carolina ${ }^{163}$ the Court, with a lone dissent from Justice Sotomayor, held that a police stop based on an erroneous police belief that a criminal law had been broken did not violate the Fourth Amendment provided that the officer's "not ... perfect" grasp of the law was "reasonable." 164 Heien extends Leon's logic to the substance of the Fourth Amendment. Again, Heien's justification is elusive: it is not obvious why police officers charged with executing the law should not work under an incentive to become accurately informed about it, especially when citizens work under a parallel obligation. ${ }^{165}$ The Court's own deterrence rationale no longer explains (if it ever did) why fault was extended to the Fourth Amendment's suppression remedy. Rather, as with the constitutional tort context, a close study of doctrinal development suggests that the Court is the principal architect in this fault rule, and that looming large among its motives is an institutional concern with judicial economy.

Once nested in Fourth Amendment law, the fault rule proved contagious across remedial boundaries within criminal procedure law. Consider the Fifth Amendment prophylactic regime of Miranda $v$. Arizona. ${ }^{166}$ Early cases applying Miranda eschewed any notion of

163. Heien v. North Carolina, 135 S. Ct. 530 (2014).

164. Id. at 536 (holding that a "reasonable mistake of law" by police did not violate the Fourth Amendment).

165. Mistakes of law occur in the Fifth Amendment self-incrimination context and are not given exculpating significance there. See, e.g., Connecticut v. Barrett, 479 U.S. 523, 531-32 (1987) (Brennan, J., concurring) (noting that the petitioner did not invoke his Fifth Amendment right to counsel when he agreed to speak to police, but not to give a written statement without a lawyer present); Moran v. Burbine, 475 U.S. 412, 424-26 (1986) (finding affirmative police misrepresentations about availability of defendant's lawyer did not undermine waiver of Fifth Amendment rights). The Court has also taken a pitiless view of habeas petitioners' filing errors, even when those errors are made in reliance upon a judge's directions. See Bowles v. Russell, 551 U.S. 205, 207-08 (2007). It is, to be sure, possible to imagine justifications for treating officials' and citizens' errors asymmetrically. Yet the repeated character of officials' encounters with the law, the distribution of educational and other epistemic resources, and the simple possibility of training - with the concomitant risk of moral hazard from judicial exculpation of official error-all list against the sort of unilateral mercy that the Court has evinced.

166. Miranda v. Arizona, 384 U.S. 436, 447-48 (1966) (discussing the necessity of placing a limit on the methods useable by police conducting custodial interrogations). Miranda requires the delivery of four warnings and the securing of a waiver of Fifth Amendment rights prior to custodial interrogation. Id. at 467-76. The failure to give the warnings, however, does not necessarily lead to exclusion even absent fault. See, e.g., Michigan v. Tucker, 417 U.S. 433, 44951 (1974) (permitting the use of testimony given by third party whose identity was derived from a statement obtained in violation of Miranda); Harris v. New York, 401 U.S. 222, 224-26 (1971) (allowing the use for impeachment purposes of voluntary statements obtained in violation of Miranda). Moreover, it is unclear whether Miranda is constitutionally compelled. When 
fault. ${ }^{167}$ A fault rule entered Fifth Amendment jurisprudence in litigation over a police tactic that involved violating Miranda by failing to give warnings, giving the requisite warnings, and then rehearsing the same questions to obtain testimony that had previously been aired. In Oregon v. Elstad, ${ }^{168}$ the Court held that a second statement obtained after warnings could be admitted even if it was arguably the product of a first unwarned statement. ${ }^{169}$ Confronted by a deliberate strategy of using unwarned questioning to inform Mirandized interrogation in Missouri v. Seibert ${ }^{170}$ however, the Court fragmented, with a plurality adopting an approach that purported to focus solely on the efficacy of any warning eventually delivered. ${ }^{171}$ Justice Kennedy's concurrence, however, focused on the intentional quality of the Miranda violation, importing a notion of fault (albeit not the unreasonable fault that characterizes other remedial domains). ${ }^{172}$ Subsequently, several lower courts have looked to officers' intentions to analyze Miranda violations in the two-stage interrogation context. ${ }^{173}$ Hence, the operative Fifth Amendment remedial rule in Seibert's wake increasingly tracks the fault-based logic of Leon and its progeny in sorting for deliberate constitutional violations and disregarding negligent violations. Fault's seemingly inexorable spread as a threshold trigger for suppression remedies confirms its ascendance as a regulative principle for individualized constitutional remedies in general.

\section{Fault in Postconviction Habeas Jurisprudence}

The third remedial domain in which fault has come to play a pivotal rationing function is postconviction habeas review. Since 1867, the postconviction writ has provided a procedural vehicle for state

presented with the question whether Miranda violations can be enforced via constitutional tort suits, the Court fragmented. See Chavez v. Martinez, 538 U.S. 760 (2003).

167. See, e.g., Arizona v. Roberson, 486 U.S. 675, 682-83 (1988).

168. Oregon v. Elstad, 470 U.S. 298 (1985).

169. Id. at 306-10.

170. Missouri v. Seibert, 542 U.S. 600 (2000).

171. Id. at 604-06 (plurality opinion) (Souter, J.).

172. Id. at 622 (Kennedy, J., concurring).

173. See, e.g., United States v. Pacheco-Lopez, 531 F.3d 420, 427 n.11 (6th Cir. 2008) (declining to resolve the issue because the statement would be suppressed under any applicable framework); United States v. Materas, 483 F.3d 27, 33 (1st Cir. 2007) (noting the officer acted in good faith, and discussing the plurality's test); United States v. Stewart, 388 F.3d 1079, 1090 (7th Cir. 2004) (stating that "at least as to deliberate two-step interrogations," there is a "presumptive rule of exclusion, subject to a multifactor test"). 
and federal prisoners to challenge their confinement on the ground that there was a constitutional error in their initial criminal adjudication. ${ }^{174}$ The present law of postconviction review is labyrinthine. ${ }^{175}$ I focus here on advancing three relatively limited claims. First, a fault rule plays the same gatekeeping function in the habeas context as it does in the constitutional tort and the exclusionary rule domains. Second, even though postconviction habeas is necessarily a statutory creation, it has been the Court that has taken the laboring oar by endowing fault with a regulative function. Tracking the etiology of the fault rule in the constitutional tort context, the parallel habeas rule has evolved incrementally through a process of common-law adjudication. And third, this regulative function is best explained in terms of judicial-economy concerns. ${ }^{176}$

From its inception, the midcentury reinvigoration of collateral relief from state criminal convictions attracted fierce criticism for its psychological and practical toll upon state criminal justice systems. ${ }^{177}$ It was not, however, until 1989 that the Court in Teague v. Lane ${ }^{178}$ began to carve out a safe harbor for state officials who complied with contemporaneously applicable constitutional rules-and correspondingly began to deny relief to litigants who failed to identify an especially glaring constitutional error. ${ }^{179}$ Formally a rule about retroactivity, Teague in fact tracked the early versions of fault found in cases such as Pierson v. Ray ${ }^{180}$ and Arizona v. Evans. ${ }^{181}$ By holding

174. See Habeas Corpus Act of 1867 , ch. 28, § 1, 14 Stat. 385, 385-86. For a comprehensive history of postconviction review, see Larry W. Yackle, The Habeas Hagioscope, 66 S. CAL. L. REV. 2331, 2350-76 (1993).

175. I have offered a synthesis in Huq, supra note 9, at 531-53.

176. For an earlier account of the primacy of judicial preferences over the shape of habeas, see id. at 523; see also John H. Blume, AEDPA: The "Hype" and the "Bite," 91 CORNELL L. REV. 259, 262 (2006) ("While the Court maintains that the scope of the writ is primarily for Congress to determine, it does not, in my view, really believe that to be true.... [It] has assumed a fair share of the responsibility for determining the scope of habeas review, or how much habeas is enough.").

177. See, e.g., Paul M. Bator, Finality in Criminal Law and Federal Habeas Corpus for State Prisoners, 76 HARV. L. REV. 441, 452-53 (1963) (arguing that finality is a critical element of the criminal justice system which is undermined by procedural elements which permit extensive collateral challenges to final sentencing).

178. Teague v. Lane, 489 U.S. 288 (1989).

179. Id. at 301.

180. Pierson v. Ray, 386 U.S. 547, 553-54 (1967). See supra notes 96-99 and accompanying text.

181. Arizona v. Evans, 514 U.S. 1, 14-15 (1995). See supra note 151 and accompanying text. 
that habeas petitioners could not obtain relief based on violations of constitutional rules announced after their convictions became final, ${ }^{182}$ it held state officials responsible for extant constitutional law, but not potential expansions. That Teague was inspired by the logic of qualified immunity was immediately apparent to sophisticated observers, even if not explicit in the decision. ${ }^{183}$ Just how far the Court would take the analogy would take time to surface.

The next doctrinal move toward a fault rule in habeas came a year later. The Court held that state-court convictions would be assessed for Teague novelty against a specific and granular version of the precedent, not the general principle of constitutional law embodied by the case.$^{184}$ This development paralleled the demand for specificity in constitutional tort law. ${ }^{185}$ As in the constitutional tort context, the demand that habeas petitioners identify a specific rule extant at the time their convictions became final meant that "any decision, reasonably distinguishable on its facts from prior decisions," could be ranked as an unenforceable new rule, especially as the mere fact of "actual disagreement among courts" counted as evidence of reasonable disagreement. ${ }^{186}$

Here, the evolution of fault in postconviction review diverges from its trajectory in the constitutional tort and exclusionary rule contexts: unique to the habeas context is a measure of congressional involvement in the form of the 1996 Anti-Terrorism and Effective Death Penalty Act (AEDPA) ${ }^{187}$ AEDPA imposed a suite of new constraints on postconviction petitions, including a new statute of limitation, more stringent rules against seriatim petitions, and a more

182. Teague, 489 U.S. at 301; see also Linda Meyer, "Nothing We Say Matters": Teague and New Rules, 61 U. CHI. L. REV. 423, 425 (1994) (characterizing and criticizing Teague's holding that "convictions should not be overturned on the basis of constitutional violations that state courts could not have known of, let alone avoided, at the time a case was tried").

183. See Richard H. Fallon \& Daniel J. Meltzer, New Law, Non-Retroactivity, and Constitutional Remedies, 104 HARV. L. REV. 1731, 1735 (1991) (drawing this comparison).

184. See Butler v. McKellar, 494 U.S. 407, 409, 414-15 (1990). It is indicative of conscious borrowing of doctrinal innovations from other remedial domains that Chief Justice Rehnquist's Butler opinion cites Leon with approval. Id. at 414. The convergence of qualified immunity and habeas doctrine is noted in Ann Woolhandler, Demodeling Habeas, 45 STAN. L. REV. 575, 63540 (1993).

185. See supra note 108 and accompanying text.

186. Meyer, supra note 182, at 442; see also Fallon \& Meltzer, supra note 183, at 1761 (citing Butler as an example of the "starkly positivist view" that "when consensus dissolves ... judicial formulation of new law is rather unconstrained").

187. Anti-Terrorism and Effective Death Penalty Act, Pub. L. No. 104-132, 110 Stat. 1214 (1996) 
onerous standard of review. ${ }^{188}$ But in terms of its key fault rule, AEDPA was largely anticipated by judicial developments, and the effect of AEDPA has proved to be largely a function of judicial glosses-interpretations that have altered dramatically over time absent any congressional updating. ${ }^{189}$ The semblance of congressional control, in short, is largely illusory: calibration of the fault rule in habeas jurisprudence has, in significant measure, fallen within judicial discretion.

The primacy of judicial policy discretion in fault's emergence can be perceived by placing AEPDA in a larger context. Prior to AEDPA, Teague deference to state-court determinations applied solely to pure questions of law, not the mixed questions of law and fact that dominate in habeas practice. ${ }^{190}$ Asked to extend Teague deference prior to AEDPA in 1992, the Court splintered in Wright $v$ West ${ }^{191}$ with Justice Thomas's opinion pressing toward an expansion of Teague securing only two other votes. ${ }^{192}$ What the Court could not muster a majority to install by common-law adjudication, Congress was able to push through in the heated aftermath to a major domestic terrorism incident. ${ }^{193}$ Four years after West, Congress included in AEDPA stringent standards of review for legal and factual error of state-court convictions. ${ }^{194}$ Assuming the state court reached the merits, AEDPA directed that its decision could be adjudged on the merits only if "contrary to, or involved an unreasonable application of, clearly established Federal law, as determined by the Supreme

188. See Blume, supra note 176, at 270-74 (summarizing AEDPA's core provisions).

189. Huq, supra note 9, at 530-32, 531 n.42.

190. See Miller v. Fenton, 474 U.S. 104, 112 (1985) (stating that mixed questions of fact and law are "subject to plenary federal review" on habeas); accord Wright v. West, 505 U.S. 277, 289, 294 (1992) (noting validity of Miller after Teague).

191. Wright v. West, 505 U.S. 277 (1992).

192. Id. at 294 (suggesting, without holding, that deference should be extended to mixed questions of fact and law).

193. Notwithstanding Justice Thomas's failure to forge a majority in West, subsequent majority opinions echoed his language, rather than the more generous terms of the West concurrences. See, e.g., O'Dell v. Netherland, 521 U.S. 151, 156 (1997) ("[W]e will not disturb a final state conviction or sentence unless it can be said that a state court, at the time the conviction or sentence became final, would have acted objectively unreasonably by not extending the relief later sought in federal court.”); Graham v. Collins, 506 U.S. 461, 467 (1993) (stating that federal habeas relief is appropriate only if "reasonable jurists hearing petitioner's claim at the time his conviction became final would have felt compelled by existing precedent to rule in his favor" (citation omitted)).

194. Pub. L. No. 104-132, 110 Stat. 1214 (codified at 28 U.S.C. § 2254(d)(1) \& (2) (2012)). 
Court of the United States." ${ }^{195}$ Like qualified immunity, this is a gatekeeping rule. Habeas petitioners who surmount that hurdle still have to establish an independent entitlement to constitutional relief. ${ }^{196}$

As enacted, AEDPA's core gatekeeping rule, codified in 28 U.S.C. § 2254(d)(1), merely accomplished what Justice Thomas exhorted in West. It extinguished most de novo review in federal habeas consideration of state criminal convictions in favor of a faultbased standard akin to the demand for evidence of an unambiguously unconstitutional action in constitutional tort law. ${ }^{197}$ That fault rule, moreover, applied to not just questions of law but also mixed questions of law and fact. As a legislative enactment, AEDPA thus mimicked previously expressed judicial preferences.

But the fault rule of $\S 2254(d)(1)$ did not remain fixed. Notwithstanding the absence of formal statutory changes, the Court has incrementally altered its interpretation of that provision to the point where relief is available only when a state-court violation of constitutional rights is, in effect, grossly negligent or intentional. This process of common-law adjudication has over time aligned the fault rule for habeas with the fault rule for postconviction relief and for suppression remedies. This process of shifting legal meaning in the absence of statutory change suggests again that the relative strength of the fault rule even under AEDPA has been a function of judicial preference rather than the plain meaning of the statutory text.

Section 2254(d)(1) was first interpreted by the Supreme Court in the 2000 case of Williams v. Taylor ${ }^{198}$ to permit merits consideration of a habeas petitioner's claim only when "the state court arrives at a conclusion opposite to that reached by this Court on a question of law or if the state court decides a case differently than this Court has on a set of materially indistinguishable facts," or alternatively, when the state court "identifies the correct governing legal principle from this Court's decisions but unreasonably applies that principle to the facts

195. 28 U.S.C. $\$ 2254(d)(1)$. Factual errors are cognizable only if "unreasonable." 28 U.S.C. $\S 2254(\mathrm{~d})(2)$. The latter provision, however, interacts with other elements of AEPDA in ways that have not yet been fully resolved. See, e.g., Wood v. Allen, 558 U.S. 290, 293 (2010) (noting a circuit conflict about how the reasonableness rule in $\S 2254(\mathrm{~d})(2)$ interacts with the presumption in favor of state court factual conclusions in $\$ 2254(\mathrm{e})(1)$, but declining to resolve it).

196. See 28 U.S.C. $\$ 2254$ (a).

197. James S. Liebman, Apocalypse Next Time?: The Anachronistic Attack on Habeas Corpus/Direct Review Parity, 92 ColuM. L. REV. 1997, 2015-16 (1992) (noting that de novo review on habeas was the central target of Justice Thomas's critique).

198. Williams v. Taylor, 529 U.S. 362 (2000). 
of the prisoner's case." ${ }^{199}$ While this standard might sound demanding, the Williams plurality expressly rejected an even harsher circuit court gloss on $\S 2254(d)(1)$ to the effect that "a state-court judgment is 'unreasonable' (and hence invalid) only if all reasonable jurists would agree that the state court was unreasonable, and granted habeas relief." ${ }^{200}$

Over the subsequent fifteen years, the Court recalibrated the meaning of AEDPA deference, and adopted that lower-court standard, despite Congress's failure to amend § 2254(d)(1) ${ }^{201}$ By 2011, Justice Kennedy could say on behalf of a supermajority of the Court that habeas relief was warranted for legal error under AEDPA only if "there is no possibility fair-minded jurists could disagree that the state court's decision conflicts with this Court's precedents." ${ }^{202}$ Subsequent to that reformulation of the $\S 2254$ (d)(1) standard, the Court further narrowed the availability of review by holding that the "clearly established" federal law relevant to the $\S 2254(\mathrm{~d})(1)$ inquiry encompassed only decisions handed down when the state court ruled, rather than when that ruling became final. ${ }^{203}$ Important to my argument here, this decision was unanimous: the fault rule is uncontroversial across ideological lines in the habeas context, just as it is uncontroversial in the constitutional tort and (sometimes) in the exclusionary rule context. Accordingly, there is a wide consensus within the Court that habeas relief should be available now only where a petitioner can demonstrate "the exceptional blameworthiness of the state ${ }^{204}$ - a state of affairs that parallels developments in the constitutional tort and the exclusionary rule contexts.

In sum, the present crystallization of the fault rule in postconviction habeas is a function of judicial rather than congressional preferences. As early as 1953, Justice Jackson worried

199. Id. at 412-13 (2000).

200. Id. at 377 (emphasis added) (discussing the interpretation of $\S 2254(\mathrm{~d})(1)$ applied in Green v. French, 143 F.3d 865, 870 (4th Cir. 1998)).

201. For a detailed account of this process, see Huq, supra note 9, at 536-41.

202. Harrington v. Richter, 562 U.S. 86, 102 (2011) (8-0 decision). The court in Harrington further stated that only "extreme malfunctions in the state criminal justice system" warrant relief. Id. (citation omitted). Although Harrington was not unanimous, it has been cited approvingly in subsequent unanimous opinions. See, e.g., Nevada v. Jackson, 133 S. Ct. 1990, 1992 (2013) (per curiam); Metrish v. Lancaster, 133 S. Ct. 1781, 1787 (2013).

203. Greene v. Fisher, 132 S. Ct. 38, 45 (2011).

204. Huq, supra note 9 , at 581. 
about the demoralizing effect of a "flood" of habeas cases. ${ }^{205}$ His worry did not abate over time. To the contrary, the volume of habeas petitions increased by more than one third between the mid-1970s and the late 1989 Teague rule. ${ }^{206}$ The year that Teague was decided, Justice Kennedy (albeit writing in dissent) warned against decisions that "increase prisoner litigation and add to the burden on the federal courts." ${ }^{207}$ During the 1980 s both Chief Justice Rehnquist and Justice Powell frequently spoke out about the costs of habeas in terms of delay, especially in the capital context. $^{208}$ Simultaneously, administration officials such as the Attorney General decried "the flood of habeas corpus petitions engulfing our federal courts." ${ }^{209}$ The story recounted here-in which a fault rule is adopted at the Court's urging and then gradually rendered more onerous through commonlaw recalibration-is one that is most easily explained, at least in substantial part, by the institutional interests of the judiciary.

\section{The CAUSAl Link BETWEen REMEDIAL RATIONING AND JUDICIAL INDEPENDENCE}

This Part advances the causal claim that fault, as a regulative principle for rationing scarce judicial resources, finds at least some causal foundation in the institutional independence of the federal judiciary above and beyond the ideological and policy-focused concerns that immediately spring to mind. I develop four arguments

205. Brown v. Allen, 344 U.S. 443, 537 (1953) (Jackson, J., concurring) ("It must prejudice the occasional meritorious application to be buried in a flood of worthless ones. He who must search a haystack for a needle is likely to end up with the attitude that the needle is not worth the search.").

206. Brandon L. GARRETT \& LEE Kovarsky, Federal HabEAs Corpus: EXECUTIVE DETENTION AND POST-CONVICTION LitigAtion 135 (2013) (presenting data on state postconviction filings between 1941 and 2010).

207. Harris v. Reed, 489 U.S. 255, 259-60 (1989) (Kennedy, J., dissenting). Marin Levy has demonstrated that the Court has maintained an inconsistent view toward floodgates arguments in the habeas context, sometimes accepting them and sometimes repudiating them as inconsistent with the statutory text. Marin K. Levy, Judging the Flood of Litigation, 80 U. CHI. L. REV. 1007, 1043-49 (2013). Levy's focus, however, is on the kind of arguments the Court deploys, and not the effects of doctrine on caseload volumes. My aim is to explain the evolving contours of doctrine, and for that purpose rhetoric is not necessarily probative.

208. Bryan A. Stevenson, The Politics of Fear and Death: Successive Problems in Capital Federal Habeas Corpus Cases, 77 N.Y.U. L. REV. 699, 723-25 (2002).

209. Ira P. Robbins, Whither (or Wither) Habeas Corpus?: Observations on the Supreme Court's 1985 Term, 111 F.R.D. 265, 266-67 (1987) (footnote omitted). Rhetorical invocation of a "flood" of habeas petitions dates back at least to Professor Bator's landmark article. See Bator, supra note 177 , at 506 . 
for the conclusion that judicial independence-understood as the federal judiciary's autonomy, not a characteristic of any individual judge-has played a role in catalyzing the fault-based rationing of constitutional remedies. First, building on evidence presented in Part I, I repudiate arguments for attributing fault's contours to Congress or the strategic behavior of litigants. Second, I suggest reasons for concluding that the doctrinal developments described in Part I were not motivated wholly by ideological change. These two lines of arguments clear space for alternative explanations focused on institutional interests. The third argument I develop is a historical account of those institutional interests that adds context and affirmative circumstantial evidence for attributing the fault rule to judicial independence. Finally, I present a powerful piece of circumstantial evidence: the fault rule does not encompass all forms of constitutional remediation, and its scope is better explained by institutional, rather than ideological, interests.

\section{A. Fault as a Judicial or a Congressional Rule}

The first piece of evidence linking the gatekeeping fault rule for individual constitutional remedies to the institutional interests of the federal judiciary is the origin of that rule: as Part I suggested, it is impossible to attribute the fault rule's emergence to legislative initiative. To the contrary, it has emerged from the judiciary via common-law adjudication, with only occasional support from the legislative branch of the federal government. Further, this fault rule cannot be ascribed merely to the different incentives and resources of litigants.

1. Fault as a Legislative Imposition? One implication of the analysis offered in Part $\mathrm{I}$ is that Congress, notwithstanding its formally plenary control of federal courts' jurisdiction, ${ }^{210}$ plays little direct role in crafting constitutional remedies. ${ }^{211}$ That analysis shows that at least in the individual remedies domain, Congress's influence

210. U.S. CONST. art. III, $\S 1$, cl. 1 ("The judicial power of the United States, shall be vested in one supreme Court, and in such inferior Courts as the Congress may from time to time ordain and establish.").

211. This is not to say that legislators do not play an indirect role. Docket pressures in statutory cases for example influence not only adjudicative procedures, but also substantive outcomes. Bert I. Huang, Lightened Scrutiny, 124 HARV. L. REV. 1109, 1115 (2011) (finding that "when flooded by the [administrative] agency cases, . . . circuit courts began to reverse district court rulings less often-in the civil cases"). 
is notable mainly by its absence. This is true in regard to both the creation and the evisceration of remedies. To be sure, Congress was responsible for enacting both a civil-damages remedy against states for constitutional violations in 1871 and a postconviction habeas writ in $1867 .{ }^{212}$ But both remedies lay dormant for three-quarters of a century before being revived by the Court. And, as Part I demonstrated at length, the subsequent contraction of habeas review, the exclusionary rule, and constitutional tort actions have also largely been the work of the courts rather than Congress. ${ }^{213}$ This is most obviously so with qualified immunity, a doctrine unembarrassed by any purchase in statutory text, but openly motivated by the Court's own "considerations of public policy" since the 1970s. ${ }^{214}$ That doctrine "represent[s] a remarkable exercise of judicial creativity," not an exemplar of legislative control. ${ }^{215}$

This is not to say Congress plays no role at all. In some respects, Congress has seconded the Court's campaign to constrain individual constitutional remedies. But its main interventions, AEPDA and the Prison Litigation Reform Act ${ }^{216}$ were enacted in 1996-many years after the main elements of the fault-based regime described in Part I were already in place. ${ }^{217}$ As Part I.D. explored at length, AEDPA's role in catalyzing the fault rule in habeas is overstated: that rule, now embodied in $\S 2254(d)(1)$, was anticipated by Justice Thomas four years before AEDPA's enactment, and the writ's effectiveness has fluctuated over time as the Court's view of it has grown increasingly minatory. To understand AEDPA's installation of fault in $\S 2254(\mathrm{~d})(1)$ as a de facto delegation to the Court, which would then independently calibrate that rule, is, moreover, consistent with a legislative history that is ambiguous, conflicted, and far less amenable

212. See supra Part I.A.

213. See supra Part I.A.

214. Butz v. Economou, 438 U.S. 478, 506-07 (1978); see supra Part I.B.1.

215. James E. Pfander, Iqbal, Bivens, and the Role of Judge-Made Law in Constitutional Litigation, 114 PENN ST. L. REV. 1387, 1389 (2010).

216. Prison Litigation Reform Act, Pub. L. No. 104-134, §§ 801-810, 110 Stat. 1321, 1321-66 (1996)

217. This is not to say that these measures did not meaningfully supplement previous judicial efforts at rationing. The Prison Litigation Reform Act, for example, was "highly successful in reducing litigation, triggering a forty-three percent decline over five years." Margo Schlanger, Inmate Litigation, 116 HARV. L. REV. 1555, 1694 (2003). 
to unilaterally statist readings than the Court has sometimes suggested. ${ }^{218}$

In other respects, Congress has either been rebuffed or taken a more lenient view of constitutional plaintiffs than the Court. On the one hand, on some occasions, Congress intervenes, seemingly to promote a trend a majority of the Court has already endorsed, and its intrusion is deemed by the Justices to be an insult to judicial suzerainty over constitutional interpretation. Justices, not legislators, therefore have the last word for all practical purposes over the remedial dispensation. In the wake of Miranda v. Arizona, for example, Congress directed that a statement made by a defendant in custody "shall be admissible in evidence if it is voluntarily given." ${ }^{219} \mathrm{In}$ Dickerson v. United States, ${ }^{220}$ however, the Court notoriously held that Congress could not supersede Miranda because the latter had announced a "constitutional rule,"221 a ruling that rested upon "a strong statement of judicial supremacy in constitutional interpretation" rather than a shared hermeneutic responsibility. ${ }^{222}$

On yet other occasions, Congress has been more solicitous of plaintiffs seeking constitutional remedies than the Court. For example, rather than narrowing Bivens, Congress has taken care to preserve that remedy when regulating government tort liability via the Westfall Act. ${ }^{223}$ The Westfall Act virtually immunizes federal government officials from state common-law tort liability, substituting the government as a defendant upon the issuance of a certification by the Attorney General. Congress, however, expressly declared the exclusivity rule inapplicable to suits brought against government officials "for a violation of the Constitution of the United States," category that most obviously reaches Bivens actions. In short, even in limiting governmental liability, Congress was careful to preserve

218. Lee Kovarsky, AEDPA's Wrecks: Comity, Finality, and Federalism, 82 TuL. L. REV. 443, 445 (2007) ("Given what we know about AEDPA's legislative history, there is little support for the argument that courts should interpret AEDPA's ambiguities with any particular purposes in mind.").

219. See Pub. L. No. 90-351, § 3501(a), 82 Stat. 197, 210 (codified as amended at 18 U.S.C. $\S 3501$ (a) (2012)).

220. Dickerson v. United States, 530 U.S. 428 (2000).

221. Id. at 460 .

222. Michael C. Dorf \& Barry Friedman, Shared Constitutional Interpretation, 2000 SUP. CT. REV. 61, 62.

223. Federal Employees Liability Reform and Tort Compensation Act of 1988 (Westfall Act), Pub. L. No. 100-694, 102 Stat. 4563.

224. 28 U.S.C. $\$ 2679$ (b)(2)(A) (2012). 
individual-officer suits created by the Court. This is in striking contrast to the Court's hostility to Bivens actions. ${ }^{225}$

A possible rejoinder to this line of argument might posit that the Court operates in the shadow of legislative correction. ${ }^{226}$ On this view, it is impossible in the absence of a constitutional ruling to attribute doctrinal change to judicial preferences given the omnipresent possibility of legislative correction. As a theoretical matter, this view fails to account for the nature of legislation produced by a bicameral legislative system attended by a presidential veto. A now canonical body of work in political science demonstrates that in any political system with "many veto players separated by large ideological distance... legislation can only be incremental.,"227 Moreover, as the complexity, difficulty, and enactment costs of legislative specification rise, legislators will tend more and more to delegate decisions rather than resolve hard questions themselves. ${ }^{228}$ As a result, "[t]he constitutional process for enacting legislation, which requires all legislative proposals to pass through two chambers of Congress and be presented to the President (or, in the event of a presidential veto, to survive supermajority votes in the House and Senate), provides considerable protection for federal jurisdiction."

As an empirical matter, the argument from legislative dominance grossly overstates the efficacy of congressional control. ${ }^{230}$ As Professor Tara Grove has documented, "[t]he history of federal jurisdiction from the late nineteenth century to the present day demonstrates that the lawmaking procedures of Article I have repeatedly safeguarded the federal judiciary." ${ }^{231}$ Widening the lens, empirical work by Professor William Eskridge and others shows the probability of

225. See Pfander \& Baltmanis, supra note 45, at 118 (noting that the Court "has grown a good deal more circumspect" in extending Bivens to new doctrinal contexts).

226. I have not been able to locate any published work taking this position, but the argument has been pressed upon me in correspondence and conversations with much eloquence and force by Mike Seidman.

227. George Tsebelis, Veto Players and Law Production in Parliamentary Democracies: An Empirical Analysis, 93 AM. POL. SCI. REV. 591, 605 (1999). Tsebelis is describing parliamentary systems, but the point applies here.

228. David Epstein \& Sharyn O'Halloran, Delegating Powers: A Transaction COSt Approach to Policy-Making Under SEPARATE POWERS 197 (1999).

229. Tara Leigh Grove, The Structural Safeguards of Federal Jurisdiction, 124 HARV. L. REV. 869, 871 (2011).

230. For an empirical test that finds little evidence that the Court anticipates legislative correction, see Ryan J. Owens, The Separation of Powers and Supreme Court Agenda Setting, 54 AM. J. POL. SCI. 412, 419-24 (2010).

231. Grove, supra note 229, at 916. 
congressional override to be diminishing over time, with successful legislation characterized by bipartisan efforts at updating regulatory policy, rather than controversial and divisive "corrections" of Supreme Court errors. ${ }^{232}$ There is little cause for a policy-minded Court, that is, to anticipate legislative intervention by trimming its sails.

2. Fault as an Outcome of Litigant Incentives? If legislative incentives do not predict or explain the use of fault to ration constitutional remedies, is there some other factor exogenous to the federal courts that might do explanatory work? More than forty years ago, Professor Marc Galanter pointed out that "[r]epeat play" litigants, who are able to identify relatively technical issues upon which liability turns, will, all else being equal, prevail more frequently than one-shot claimants. ${ }^{233}$ Consistent with this insight, the Solicitor General acting on behalf of the United States enjoys an unusual success rates in the Court. ${ }^{234}$ That office is perhaps uniquely situated to stymie effective channels of constitutional redress. Can the fault rule then be attributed to the ability of government litigants to coordinate with low transaction costs, to select favorable test cases for certiorari review, and to persist where individual litigants might sag?

The short answer is no. Litigant resources cannot explain the emergence and migration of fault that was described in Part I for a number of reasons. First, it is easy to overstate the government's success rate (especially of late), ${ }^{235}$ and to forget that there are

232. Matthew R. Christiansen \& William N. Eskridge, Jr., Congressional Overrides of Supreme Court Statutory Decisions, 1967-2011, 92 TEX. L. REV. 1317, 1319 (2014) (finding that after the 1990s, "overrides declined as dramatically as they had ascended"). Further, "override statutes frequently supported by bipartisan majorities in Congress [] have as their stated goal the updating of public law, rather than 'correction' of judicial mistakes." Id. at 1320. It is very unlikely that the Justices imposing the fault rule did so because they anticipated a bipartisan majority in both Houses that would overrule them otherwise. For an even more pessimistic view of Congress's power to override judicial decisions, see Richard L. Hasen, End of the Dialogue? Political Polarization, the Supreme Court, and Congress, 86 S. CAL. L. REV. 205, 217 (2013).

233. Marc Galanter, Why the "Haves" Come Out Ahead: Speculations on the Limits of Legal Change, 9 LAW \& SOC'Y REV. 95, 97 (1974) (drawing the distinction).

234. For example, approximately seventy percent of the cases recommended for a certiorari grant by the Solicitor General are reviewed by the Court. See, e.g., Adam D. Chandler, The Solicitor General of the United States: Tenth Justice or Zealous Advocate?, 121 YALE L.J. 725, 728 (2011).

235. See Charles Hurt, The Supreme Court's Biggest Loser: Barack Obama, WASH. TIMES (July 1, 2014), http://www.washingtontimes.com/news/2014/jul/1/the-supreme-courts-biggestloser-barack-obama/ [http://perma.cc/H73T-Q6AJ] (arguing that the Obama administration in 2014 suffered an unusual string of high-profile losses). 
organized interest groups on the other side of many constitutionalrights issues, ranging from property-rights advocates to organizations promoting the interests of discrete and insular racial and ethnic groups. Second, many of the pivotal changes to the doctrine have been effected sua sponte by the federal courts, rather than flowing from prolonged litigation campaigns by organized government interests. Recall for example that the catalyst for the first iteration of a "good faith" rule in the exclusionary rule context was the Court's decision to add a question to a certiorari petition presenting a Fourth Amendment issue. ${ }^{236}$ In the habeas context, the Court initially rejected the narrowest reading of $\S 2254(\mathrm{~d})(1)$, and then of its own initiative tightened up that standard in a series of cases in which no party demanded such increased scrutiny. ${ }^{237}$

In short, reliance on congressional preferences or litigant asymmetries is not persuasive as a theoretical matter or as a matter of fit with the observed processes of doctrinal change. The gatekeeping rule for constitutional remedies is better understood as a function of judicial preferences.

\section{B. Judicial Ideology as a Cause of Remedial Rationing}

A considerable body of scholarship identifies the ideological roots of changes to constitutional doctrine in the late 1970s and 1980s as the Warren Court gave way to the Burger and the Rehnquist Courts. ${ }^{238}$ In light of that scholarship, the development of fault might be explained in simple ideological terms: the Court became more conservative as President Nixon and other Republicans made more appointments. ${ }^{239}$ It was also aware of, and sensitive to, changes in the crime rate in that period-changes that confirmed the worries of new conservative appointees. ${ }^{240}$ And perhaps-most cynically and

236. See Petitioner's Brief on Reargument at i, Illinois v. Gates, 462 U.S. 213 (1983) (No. 81430), 1983 WL 482675 (citations omitted).

237. Huq, supra note 9, at 540 (explaining that recent changes to the interpretation of $\S 2254(d)(1)$ were not made at the behest of the parties).

238. See, e.g., supra note 20 and sources cited therein.

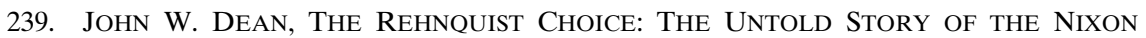
APPOINTMENT THAT REDEFINED THE SUPREME COURT 16 (2001) (recounting thenpresidential advisor William Rehnquist's advice to President Reagan to appoint "strict constructionists" to the federal courts, who "will generally not be favorably inclined toward claims of either criminal defendants or civil rights plaintiffs").

240. See Arenella, supra note 20, at 187. But see Yale Kamisar, The Warren Court (Was It Really So Defense-Minded?), The Burger Court (Is It Really So Prosecution-Oriented?), and Police Investigatory Practices, in THE Burger Court: THE COUnTER-Revolution That 
crassly-one might suppose that some of the new Justices were less than sympathetic to certain minority populations' constitutional claims. ${ }^{241}$ Given the overlapping influences of ideology, concerns about crime control, and racialized politics, it might be thought that there is no room for an account focused on the institutional interests of the Supreme Court. Making a place for institutional interests, therefore, requires some response to reductive accounts of doctrinal change.

My aim in this section is to demonstrate that whatever role ideology-whether subtly or crassly defined-played, it cannot explain wholesale the development of the fault rule. That is, I do not doubt that the changing composition of the Court over the 1970s and 1980s influenced the development of the case law. I do doubt that ideology, or the politics of crime and race, is the whole story. ${ }^{242}$ The primary evidence for my claim to this effect is simple: key precedent in all three lines of cases is surprisingly bereft of sharp ideological division. In particular, qualified immunity and habeas precedent include frequent supermajoritarian and even unanimous opinions. Dissent rates also seem to diminish with a speed and alacrity that appointment-driven change cannot adequately explain. Hence, the distribution of votes on the Court is hard to square with purely ideological accounts. I first work through this evidence, and then adduce a series of supplemental reasons for resisting crassly ideological accounts.

1. Qualified Immunity. Consider first qualified immunity. The fons et origo of much modern qualified immunity doctrine is Pierson v. Ray, an opinion by Chief Justice Earl Warren from which only Justice Douglas dissented. ${ }^{243}$ Butz v. Economou, ${ }^{244}$ which intimated the

WASN'T 62, 62-63, 90-91 (Vincent Blasi ed., 1983) (suggesting that the distinctions between the Warren and Burger Courts were based more on fear of what might happen than on the more moderate changes the Burger Court actually made).

241. See, e.g., Edward A. Purcell, Jr., Reflections on the Fiftieth Anniversary of the March and the Speech: History, Memory, Values, 59 N.Y.L. SCH. L. REV. 17, 56 (2015) ("The [Reaganera] concern with 'criminal defendants' reflected the new rhetoric of non-racial categories that nonetheless carried racial significance for many Americans.”).

242. One problem with these ideological accounts of the Court's conservative turn is their general failure to recognize the historical depth of political polarization over crime, and the complex etiology of harsh penal policy. See generally MARIE GOTTSCHALK, THE PRISON AND THE GAllows: THE Politics of MASs INCARCERATION IN AMERICA (2006) (discussing this point).

243. Pierson v. Ray, 386 U.S. 547, 558 (1967) (Douglas, J., dissenting).

244. Butz v. Economou, 438 U.S. 478 (1978). 
functional basis for qualified immunity and extended that immunity to federal officials, attracted dissents only from Justices who would have applied absolute immunity. ${ }^{245}$ The Court's full bore adoption of a functionalist logic in Harlow v. Fitzgerald similarly attracted only the lone protest of Chief Justice Burger, from a statist, pro-defendant perspective. ${ }^{246}$ The creation of absolute immunity for prosecutors in Imbler v. Pachtman, ${ }^{247}$ once more, elicited only a concurrence from Justices White, Brennan, and Marshall that largely approved of "the judgment of the Court and ... much of its reasoning." ${ }^{248}$ Today, the majority of applications of qualified immunity elicit not just a majority, but unanimity, from the Court. ${ }^{249}$ For example, Justice Scalia's 2011 statement that qualified immunity shelters "all but the plainly incompetent or those who knowingly violate the law," elicited no protests from the liberal wing of the Court, despite its distance from the qualified immunity doctrine of even the Burger Court. ${ }^{250}$ Qualified immunity-notwithstanding its potentially significant normative and distributive effects-is thus beyond debate for the current Court.

There have been instances, to be sure, in which liberal Justices resisted the increasing calcification of constitutional tort law via qualified immunity, but this resistance was to prove short lived. In Anderson v. Creighton, ${ }^{251}$ for example, Justices Stevens, Brennan, and Marshall criticized "the Court's (literally unwarranted) extension of qualified immunity," noting that the Fourth Amendment's rule of probable cause already provided officers with ample breathing room. ${ }^{252}$ By 2014, however, Anderson had become sufficiently routinized that liberal Justices not only joined opinions that cited its

245. Id. at 517 (Rehnquist, J., concurring in part and dissenting in part). Justice Rehnquist was joined by Chief Justice Burger and Justices Stewart and Stevens. Id.

246. Harlow v. Fitzgerald, 457 U.S. 800, 822 (1982) (Burger, C.J., dissenting).

247. Imbler v. Pachtman, 424 U.S. 409, 431 (1976).

248. Id. at 432 (White, J., concurring in the judgment, joined by Brennan \& Marshall, JJ.).

249. See, e.g., Plumhoff v. Rickard, 134 S. Ct. 2012 (2014) (unanimous); Pearson v. Callahan, 555 U.S. 223 (2009) (unanimous).

250. Ashcroft v. al-Kidd, 131 S. Ct. 2074, 2085, 2085-90 (2011) (quoting Malloy v. Riggs, 475 U.S. 335, 341 (1985)). Justice Ginsburg, along with Justices Breyer and Sotomayor, concurred only in the judgment, but did not object to this formulation of qualified immunity. Id. at 2087 (Ginsburg, J., concurring in the judgment).

251. Anderson v. Creighton, 483 U.S. 635 (1987).

252. Id. at 660 (Stevens, J., dissenting). 
rule, but agreed to per curiam reversals on its basis. ${ }^{253}$ And where the application of the demanding Anderson rule elicits dissents, it is a supermajority of Justices that includes both liberals and conservatives to be found insisting on a harsh application of that rule. ${ }^{254}$ In short, there is little reason to gloss the emergence of qualified immunity as a doctrinal change associated with the conservative, pro-law-and-order wing of the Court. Rather, that doctrine has long had substantial cross-ideological support-support that has only deepened over time.

Qualified immunity doctrine yields one further item of evidence that suggests the role of institutional, rather than ideological, concerns in shaping the law. In 2001, the Court held in Saucier v. $\mathrm{Katz}^{255}$ that courts engaged in a qualified immunity analysis had to follow a certain sequence of analysis starting with a mandatory "initial inquiry" into whether a constitutional rule had been violated before any determination of clearly established law. ${ }^{256}$ Writing for the Court in Saucier, Justice Kennedy explained that this analytic sequence would facilitate "the process for the law's elaboration from case to case ${ }^{\text {257 }}$ and hence ensure expeditious development of clearly established rules to serve as a predicate for constitutional tort liability. Yet eight years later, the Court in Pearson v. Callahan ${ }^{258}$ unanimously abandoned the Saucier sequencing rule in favor of a rule that allowed lower courts to forego the "initial inquiry" into the law in favor of a ruling on whether a "clearly established" rule had been violated. ${ }^{259}$ Because this reversal has the effect of decelerating the rate at which constitutional rules become clearly established, it not only increases the chances that a plaintiff subject to Pearson rule will lose, but also diminishes the chances that many other future plaintiffs will lose for want of a clearly established rule.

Pearson is telling not merely because it was unanimous, but because it was liberal Justices, led by Justice Breyer, who launched

253. See, e.g., Carroll v. Carman, 135 S. Ct. 348, 350 (2014) (per curiam) (citing Anderson); see also Tolan v. Cotton, 134 S. Ct. 1861, 1866 (2014) (per curiam) (relying on Anderson, albeit not so centrally, in the course of a summary reversal).

254. Messerschmidt v. Millender, 132 S. Ct. 1235, 1245 (2012) (relying on Anderson to dismiss Fourth Amendment claim); id. at 1251 (Breyer, J. concurring); id. (Kagan, J., concurring in part and dissenting in part); id. at 1252 (Sotomayor, J., dissenting, joined by Ginsburg, J.).

255. Saucier v. Katz, 533 U.S. 194 (2001).

256. Id. at 201.

257. Id.

258. Pearson v. Callahan, 555 U.S. 223 (2009).

259. Id. at 234 . 
the call for Saucier's reconsideration-and did so on the basis of institutional consideration. In 2004, Justice Breyer criticized Saucier on the ground that "when courts' dockets are crowded, a rigid 'order of battle' makes little administrative sense." ${ }^{\text {260 }}$ In 2007, he reiterated his concern that the rule was "wasting judicial resources." 261 That is, it was a liberal Justice who pressed first and most urgently for enlarged application of qualified immunity's fault rule in a way that predictability would conduce to less clearly established law and fewer constitutional tort recoveries. He did so expressly out of institutional concerns related to his conception of the federal judiciary's sound operation. Qualified immunity doctrine, in short, embodies powerful evidence that ideological considerations do not exhaust the causal forces motivating the rise and currently hegemonic status of faultbased gatekeeping rules.

2. Postconviction Review. A similar tale of ideological convergence can be told in respect to habeas jurisprudence. At least in the last decade or so, ideological conflict over habeas-as opposed to over the death penalty - a distinct matter often entangled in habeas cases-has almost wholly abated. Liberal and conservative Justices alike praise and enforce a fault-based regime. It is certainly true that early cases installing fault-based gatekeeping rules elicited dissents. For example, the Court's 2000 ruling on the meaning of $\S 2254(d)(1)$ 's gatekeeping rule was highly fractured. ${ }^{262}$ Even then, it is worth emphasizing the supermajority quality of many opinions. The pivotal decision of Wainwright v. Sykes, ${ }^{263}$ which installed one of the first fault-based rules for habeas, was 7-2, with only Justices Brennan and Marshall dissenting. ${ }^{264}$

Yet ideological division has proved remarkably evanescent. Even as the Court has ratcheted up the intensity of the fault threshold for habeas, the Court has coalesced into a united front in demanding that

260. Brosseau v. Haugen, 543 U.S. 194, 201-02 (2004) (Breyer, J., concurring). Lower courts echoed this concern. See Lyons v. City of Xenia, 417 F.3d 565, 580 (6th Cir. 2005) (Sutton, J., concurring) (complaining that Saucier forced decisions on "difficult and fact-intensive question[s]").

261. Morse v. Frederick, 551 U.S. 393, 430 (2007) (Breyer, J., concurring in the judgment in part and dissenting in part); see also Scott v. Harris, 550 U.S. 372, 387 (2007) (Breyer, J., concurring) ("I believe that in order to lift the burden from lower courts we can and should reconsider Saucier's requirement .....").

262. See Williams v. Taylor, 529 U.S. 362, 367, 399 (2000).

263. Wainwright v. Sykes, 433 U.S. 72 (1977).

264. Id. at 99 (Brennan, J., dissenting, joined by Marshall, J.). 
habeas petitioners satisfy Harrington $v$. Richter' ${ }^{265}$ more onerous and demanding version of the statutory fault rule ${ }^{266}$ that was rejected in 2000 by the Court at a time when it had more Republican appointees. ${ }^{267}$ Nor is Harrington an outlier ${ }^{268}$ there is a remarkable series of decisions in which a unanimous Court, often acting per curiam, has reversed habeas decisions without briefing or oral argument based on the petitioner's failure to show sufficient fault. ${ }^{269}$ These cases show that the fault rule is so uncontroversial among all the Justices, whether liberal or conservative, that they are willing to jettison their ordinary rule against error correction. ${ }^{270}$ The trajectory of habeas jurisprudence, in short, speaks to the strength of institutional, as opposed to ideological, motives as a causal force. ${ }^{271}$

3. The Exclusionary Rule. Finally, consider the exclusionary rule. A fault rule for suppression remedies was justified first in judicialeconomy terms, not in overdeterrence terms. Hence, in a pre-Leon concurrence, Justice White argued that a fault-based limitation on suppression remedies would yield a "reduction in the number of cases which will require elongated considerations of the probable-cause question." ${ }^{272}$ Nevertheless, the evidence of ideological polarization over the exclusionary rule is weaker than in qualified immunity and habeas contexts. But it is not absent. Whereas early cases such as

265. Harrington v. Richter, 131 S. Ct. 770 (2011).

266. See id. at 786; supra text accompanying note 202. Harrington was applied by a unanimous Court without dissent in Metrish v. Lancaster, 133 S. Ct. 1781, 1787 (2013). It was unanimously extended in Greene v. Fisher, 132 S. Ct. 38, 45 (2011), which held that the "clearly established" federal law relevant to the $\S 2254(d)(1)$ inquiry encompassed only decisions handed down when the state court ruled, rather than when that ruling became final.

267. Huq, supra note 9, at 581 (developing this comparison). Between 2000 and 2014, Justices Rehnquist, O'Connor, Stevens, and Souter (all Republican appointees) resigned, while Justices Roberts, Alito, Sotomayor, and Kagan (two Republican and two Democrat) were confirmed.

268. In the same Term as Harrington, a supermajority of the Court also dramatically limited the availability of evidentiary hearings in habeas. See Cullen v. Pinholster, 131 S. Ct. 1388, 140001 (2011) (7-2 decision); Huq, supra note 9, at 536-37 (explaining the impact of Pinholster).

269. See, e.g., Ryan v. Schad, 133 S. Ct. 2548 (2013) (per curiam); Nevada v. Jackson, 133 S. Ct. 1990 (2013) (per curiam); Marshall v. Rodgers, 133 S. Ct. 1446 (2013) (per curiam); Johnson v. Williams, 133 S. Ct. 1088 (2013); Martel v. Clair, 132 S. Ct. 1276 (2012) (per curiam); Greene v. Fisher, 132 S. Ct. 38 (2011).

270. See Sup. CT. R. 10.

271. For an extended argument to this effect, see Huq, supra note 9, at 586-93.

272. Illinois v. Gates, 462 U.S. 213, 267 (1983) (White, J., concurring). 
Leon attracted multiple dissents, ${ }^{273}$ more recent opinions, such as Arizona v. Evans, have attracted smaller dissents. ${ }^{274}$ And the Court's most recent extension of Leon in Heien v. North Carolina accrued only a single protest vote. ${ }^{275}$

In short, careful examination of the case law does not support the conclusion that fault-based remedial rationing is a consequence of ideological change alone. Although ideology has certainly been salient, it does not capture the whole story: Justices repeatedly emphasize caseload and judicial-economy concerns in regard to habeas, suppression remedies, and constitutional tort. And the coalitions observed in the jurisprudence belie any simple ideological account. Consistent with this ideological variation, not all of the doctrines canvassed above concern constitutional challenges typically favored by liberal Justices and disfavored by conservative Justices. Challenges to state taxes, for example, lack any obvious ideological valence and yet are hedged by a species of the fault rule. ${ }^{276} \mathrm{~A}$ Bivens claim subject to qualified immunity is available just as much to a rancher infuriated by meddling federal land officials as a racial minority subject to harassing and intrusive federal policing. ${ }^{277}$ To boil the case law down to ideology, in short, is to fail to take seriously the Court qua court, to ignore the statements of the Justices, and to blink to observed patterns of judicial coalition-formation. It is to impose a crude functionalism on a Court that, in practice, is much more supple in its thinking.

\section{Circumstantial Evidence of the Institutional Roots of the Fault Rule}

To claim that courts, rather than legislators or litigants, have been responsible for the ascendency of fault is to assert that federal judges have had both institutional means and sufficient motives to install the regime described in Part I. There is considerable historical and contemporaneous empirical evidence of both means and motive.

273. United States v. Leon, 468 U.S. 897, 928 (1984) (Brennan, J., dissenting, joined by Marshall, J.); id. at 960 (Stevens, J., concurring in part and dissenting in part).

274. Arizona v. Evans, 514 U.S. 1, 18 (2011) (Stevens, J., dissenting); id. at 23 (Ginsburg, J., dissenting, joined by Stevens, J.).

275. Heien v. North Carolina, 135 S. Ct. 530, 542 (2014) (Sotomayor, J., dissenting).

276. See Am. Trucking Ass'ns v. Smith, 496 U.S. 167, 182 (1990) (plurality opinion) (O’Connor, J.).

277. See, e.g., Wilkie v. Robbins, 551 U.S. 537, 548 (2007) (describing Fourth and Fifth Amendment claims filed by rancher against federal land officials). 
Marshaling that evidence, I advance two points here to support a causal link between judicial independence and fault-based rationing of constitutional remedies. First, notwithstanding the clichéd image of a federal judiciary as weak and dependent upon the political branches ${ }^{278}$ historians have developed an account of the federal judiciary as an institution that as a branch has accreted gradually a great deal of autonomous discretion to pursue institutional interests. ${ }^{279}$ Second, empirical work identifies caseload management as a core institutional interest of the federal judiciary. Vindicating institutional autonomy in the federal judicial context translates as managing the flow of cases. Focusing on the period of time in which the fault rule developed - the late 1970s and early 1980s-in particular reveals considerable circumstantial evidence that the Justices viewed constitutional remediation as problematic in caseload terms. Both the judiciary's means and its motives for fault-based remedial rationing, in short, are amply supported by available evidence.

1. The Judiciary's Institutional Interest in Caseload Management. Consider first the historical trajectory of branch-level independence. At the time of the Founding, the constitutional text vested Congress with broad formal authority over the jurisdictional structure and funding of the federal courts. ${ }^{280}$ Nevertheless, post-Founding developments rendered such authority increasingly formal rather than real. Rather than a function of constitutional text, therefore, judicial independence at a branch level has emerged as a result of institutional developments over the long run of American history. ${ }^{281}$ There was nothing inevitable or necessary, moreover, about this development. Instead, institutional pathways in historical time are contingent matters, vulnerable to the accidents of personality and

278. See The Federalist No. 78, at 522 (Alexander Hamilton) (Jacob E. Cooke ed., 1961) (emphasizing judicial weakness in comparison to the executive and the legislature).

279. For an account of "branch independence" as the power "to operate according to procedural rules and administrative machinery that it fashions for itself," as distinct from individual judges' independence, see Gordon Bermant \& Russell R. Wheeler, Federal Judges and the Judicial Branch: Their Independence and Accountability, 46 MERCER L. REV. 835, 83738,845 (1995).

280. U.S. CONST. art. III, §§ 1-2 (granting Congress broad jurisdictional control); see also Peter J. Smith, Textualism and Jurisdiction, 108 COLUM. L. REV. 1883, 1892-94 (2008) (noting "the traditional view" of Article III is that Congress has plenary power over federal jurisdiction).

281. See J. Mark Ramseyer, The Puzzling (In)dependence of Courts: A Comparative Approach, 23 J. LEGAL STUD. 721, 746 (1994) (arguing based on a comparative analysis that "[j]udicial independence is not primarily a matter of constitutional text"). 
exogenous shocks. Regardless of the particular pathway taken, however, it is inevitable that an institution crafted in a handful of words in 1789 would evolve, mutate, and even metastasize in unexpected ways over two hundred years of historical time. ${ }^{282}$

Recent historical work zeroes in upon the first part of the twentieth century as a turning point. During this period, the federal judiciary successfully lobbied Congress to delegate important authority over key jurisdictional and administrative powers to the bench. In 1922, for example, Congress created the Conference of Senior Circuit Judges, ${ }^{283}$ a modest entity later to develop into the Judicial Conference of the United States, a full-scale bureaucracy with statutory authority to lobby by "submit[ting] to Congress ... its recommendations for legislation.",284 In 1925, Chief Justice William Howard Taft engaged in "unprecedented efforts" to lobby Congress into granting the Supreme Court almost unfettered discretion over its caseload, near plenary authority to set its own agenda, and freedom to determine how and why it would intervene on matters of national salience. ${ }^{285}$ In 1934, Congress "was compelled to delegate power to the Court" to set rules for the judiciary in the Rules Enabling Act, signaling that "the federal judiciary had arrived as a power player in the national political scene." 286 The subsequent creation of the Administrative Office of the U.S. Courts further weakened executive branch influence on the judiciary. ${ }^{287}$ Over this period, the executive branch also extended support to the judiciary, which it viewed as a vehicle for pursuing its own political agenda, in effect checking congressional leverage of jurisdictional controls. ${ }^{288}$ The net result of

282. This is the central thesis of American Political Development (APD) theory, i.e., that "a polity in all its different parts is constructed historically, over time" such that "the nature and prospects of any single part will best be understood within the long course of political formation." KAREN ORREN \& STEPHEN SKOWRONEK, THE SEARCH FOR AMERICAN POLITICAL DEVELOPMENT 1 (2004).

283. Act of Sept. 14, 1922, ch. 306, § 2, 42 Stat. 837, 838 (current version at 28 U.S.C. $\S 331$ ).

284. Act of June 25, 1948, Pub. L. No. 80-772, § 331, 62 Stat. 683, 902 (codified as amended at 28 U.S.C. $\$ 331)$.

285. Edward A. Hartnett, Questioning Certiorari: Some Reflections Seventy-Five Years After the Judges' Bill, 100 COLUM. L. REV. 1643, 1648 (2000).

286. CROWE, supra note 23, at 224 (discussing 28 U.S.C. $\$ 2072$ (2000)).

287. Id. at 231-34.

288. Tara Leigh Grove, The Article II Safeguards of Federal Jurisdiction, 112 COLUM. L. REV. 250, 260 (2012) ("The executive has a strong incentive to use its independent role in the enactment and enforcement of federal law to preserve the scope of federal jurisdiction."); see also Mark A. Graber, Constructing Judicial Review, 85 ANN. REV. POL. SCI. 425, 435 (2005) ("The Taft, Harding, and Coolidge administrations fought to staff the federal judiciary with 
these accumulated reforms was to empower the judiciary with the institutional instruments and procedural avenues to pursue its (selfdefined) interests.

Capturing this rise in branch-level judicial independence, political scientist Kevin McGuire has assembled a longitudinal index of the federal judiciary's institutionalization. ${ }^{289}$ This index bundles measures of the Supreme Court's institutional differentiation from other federal entities, the durability of its interests, and its autonomy from other political forces. ${ }^{290}$ Measured over the twentieth century, McGuire's index evinces a steady upward trend line such that by the 1960s, the Court had become a "distinctive and independent force within the federal government. ${ }^{291}$ McGuire's conclusion is supported by a second set of studies examining how the Court exercises judicial review. These studies of time trends in judicial exercise of the power to invalidate state and federal statutes identifies a peak in the early twentieth century and another peak from the 1960s through the 1980 s. $^{292}$ To the extent that judicial willingness to invalidate duly enacted laws is a metric of judicial independence, the late twentieth century marks one of its high water marks. ${ }^{293}$

This historical evidence is complemented by a growing body of evidence that judges act upon the basis of institutional interests determined by their position within Article III. Of course, it is well

political actors prone to construe ambiguous Constitutional and statutory language against labor."). Political parties, acting across institutional lines, have also supported the growth of judicial power. See MARTIn Shapiro, COURTS: A COMPARATIVE AND POLITICAL ANALYSIS, at viii (1981) (describing courts as institutions "by which central political regimes consolidate their control over the countryside"); Howard Gillman, How Political Parties Can Use the Courts to Advance Their Agendas: Federal Courts in the United States, 1875-1891, 96 AM. POL. SCI. REV. 511, 513 (2002).

289. See McGuire, supra note 23, at 130-33.

290. Id.

291. Id. at 135. Crowe argues that judicial autonomy requires political differentiation, organization capacities, and political legitimacies-qualities that the Court obtained in the 1920s under Chief Justice Taft. Justin Crowe, The Forging of Judicial Autonomy: Political Entrepreneurship and the Reforms of William Howard Taft, 69 J. POL. 73, 76 (2007).

292. See Aziz Z. Huq, When Was Judicial Restraint?, 100 CALIF. L. REV. 579, 583, 587 (2012) (identifying the post-Civil War era as a turning point in institutional development for the Supreme Court); Keith E. Whittington, The Least Activist Supreme Court in History? The Roberts Court and the Exercise of Judicial Review, 89 NOTRE DAME L. REV. 2219, 2228 fig.1 (2014).

293. Of course, the rate of invalidation is likely also a function of the rate of passage of unconstitutional laws, and also the ideological gap between the Court and elected bodies at state and federal levels. Even without holding these constant, the higher rates of invalidation are hard to square with a Court that lacked for confidence in its own institutional station. 
known that the policy preferences of appointing presidents powerfully shape the distribution of federal judicial candidates presented to and confirmed by the Senate. ${ }^{294}$ A recent empirical study by Professor Thomas Keck thus concludes that judicial motivations "are shaped in part by a sense of institutional duty."295 Keck examined three possible explanations for the Supreme Court's decision to invalidate federal statutes: partisan differences, policy disagreements, and institutional disagreements. Contra accounts that focus on the partisan drivers of judicial review, Keck concluded that more than 60 percent of federal laws struck down between 1981 and 2005 are consistent with an institutional account of judicial review in which the Justices' "motivation is the desire to defend judicial authority against incursions from the other branches." ${ }^{, 296}$ In contrast, most instances of judicial review in that time period "fit uneasily" with a policy or partisan differences account. ${ }^{297}$ Keck's study concerns federal statutory invalidations, not the regulation of state criminal justice systems. But it would be extraordinary if the Justices' preferences varied not just in quality but also in kind between different domains. There is hence no reason to think that his inferences would not extend to the doctrinal areas discussed here.

If the judiciary possesses both a degree of autonomy from other branches and also a distinct understanding of its institutional interests, it becomes necessary to identify those interests. Theoretical, empirical, and self-reported data from the federal bench demonstrates that moderating the flow of cases, and in particular requests for constitutional remedies, comprises a central element of the Article III judiciary's institutional interests.

294. Susan W. Johnson \& Donald R. Songer, The Influence of Presidential Versus Home State Senatorial Preferences on the Policy Output of Judges on the United States District Courts, 36 LAW \& SOC. REV. 657, 666 (2002) (expecting to find "that the practice of senatorial courtesy might lead to judicial appointments consistent with the views of home state senators" but discovering that "presidential preference is more than twice as influential as home state senatorial preferences"); see also Barry Friedman, The Politics of Judicial Review, 84 TEX. L. REV. 257, 278 \& n.105 (2005) (noting the "predictive success of the presidential-appointment measure of [judicial] ideology").

295. Keck, supra note 25, at 323; see also Thomas Brennan, Lee Epstein \& Nancy Staudt, The Political Economy of Judging, 93 MINN. L. REV. 1503, 1506 (2009) (noting that a consensus view that "institutional factors affect judicial outcomes") (footnote omitted).

296. Keck, supra note 25 , at 336. For example, consider here the judicial response to legislative and executive efforts to roll back the Miranda rule. See Dickerson v. United States, 530 U.S. 428, 432 (2000) (invalidating purported legislative substitute for Miranda).

297. Keck, supra note 25, at 336. 
At a theoretical level, Judge Richard Posner has posited "leisure" as a central element in the judicial utility function. ${ }^{298}$ Empirical studies confirm Posner's intuition. These show that federal judges, like any other supplier of labor, are averse to excessive demands on their time. ${ }^{299}$ Because these demands are determined on an institution-wide basis, it follows that federal judges must attend to their individual interest in minimizing unwanted effort through doctrinal tools that are systemic in character. Consistent with both the narrow and the broad interpretation of institutional interests, both liberal and conservative Justices alike express concern about the ability of the federal courts to fulfill their adjudicative role given rising caseloads. ${ }^{300}$ Rising caseloads have already overwhelmed courts' ability to give individualized consideration to every discrete matter, and led to the substitution of law clerk and staff attorney consideration in lieu of Article III eyes. ${ }^{301}$

The theoretical and empirical evidence aligns with the historical record and self-reports from the Justices. By the 1980s, judges and scholars uniformly defined the problem of "judicial reform" as primarily a "problem ... of workload." ${ }^{302}$ This resulted in a series of commissions, starting with the Study Group on the Caseload of the Supreme Court, created by Chief Justice Warren Burger in 1971, to "study backlogs in judicial business, inadequacies in judicial performance, and potential reforms in in judicial organization or administration. ${ }^{\prime 303}$ The Study Group and its successors, the Commission on Revision of the Appellate System and the Hruska Commission, failed to catalyze legislative action, but nonetheless

298. William M. Landes \& Richard A. Posner, Rational Judicial Behavior: A Statistical Study, 1 J. Legal AnAlysis 775, 780 (2009); see also Jonathan R. Macey, Judicial Preferences, Public Choice, and the Rules of Procedure, 23 J. LEGAL STUD. 627, 630 (1994).

299. See generally Eric Helland \& Jonathan Klick, The Effect of Judicial Expediency on Attorney Fees in Class Actions, 36 J. LEGAL STUD. 171 (2007) (recounting empirical evidence of an effort aversion among federal judges).

300. See, e.g., Henry J. Friendly, Averting the Flood by Lessening the Flow, 59 CORNELL L. REV. 634, 642 (1974); Ruth Bader Ginsburg, Reflections on the Independence, Good Behavior, and Workload of Federal Judges, 55 U. Colo. L. REV. 1, 7-13 (1983); Lewis F. Powell, Jr., Are the Federal Courts Becoming Bureaucracies?, 68 A.B.A. J. 1370, 1371 (1982).

301. William M. Richman \& William L. ReYNOlds, InJUStice on Appeal: THE UNITED STATES COURTS IN CRISIS 83-98 (2013) (documenting declining use of oral argument and increasing use of law clerks and staff attorneys by the circuit courts of appeals under caseload pressure).

302. CROWE, supra note 23 , at 249.

303. Id. at 250-51. 
"raised awareness" of the caseload concern. ${ }^{304}$ Individual Justices continued to raise the same concern after these commissions wound up. Reflecting on the courts' experience from the 1960s through the 1980s, Chief Justice Rehnquist remarked not only on "the great increase of judicial business handled by the federal courts," but also "the increasing complexity of the issues now handled by the federal courts." ${ }^{305}$ Of course, this was not the first time that federal judges had complained of capacity constraints. ${ }^{306}$ But it seems clear that the late 1970s and 1980s were a time at which the pressures of adjudication were felt to be especially acute, and thus a warrant for both study and institutional change.

2. Caseload Management in the Era of Fault. The late 1970s and early 1980s were distinct in another way: they were the beginning of a fourfold increase in the rate of incarceration in state and federal prisons. ${ }^{307}$ At the time, crime appeared a major, and increasingly intractable, national problem. Crime rates had been rising since the 1960s, with no prospect of a plateau in sight. The national homicide rate, for example, had doubled in the decade after 1964, and was continuing to rise in $1980 .{ }^{308}$ Street-level crime was also perceived as a national problem, warranting responses from national institutions. In 1981, for example, the new Attorney General William French Smith, convened a task force to determine how federal resources could be switched from white-collar to street crime. ${ }^{309}$ Further, "[i]n the 1980 s and 1990s, criminal justice policy and practice was influenced by the

304. Id. at 251-52.

305. William H. Rehnquist, Seen in A Glass Darkly: The Future of the Federal Courts, 1993 WIS. L. REV. 1, 3.

306. During Reconstruction, for example, federal courts were tasked with a remedial role in the former Confederacy that exceeded their capacities. See LAURA F. EDWARDS, A LEGAL History OF THE Civil WAR AND RECONSTRUCTION: A NATION OF Rights 151 (2015) (describing experience of capacity constraints during Reconstruction).

307. See WESTERN, supra note 86, at 13.

308. Franklin E. Zimring, The Great American Crime Decline 5 (2007). Homicide rates would drop precipitously, and unexpectedly, in the early 1990s. Id.

309. KATHERINE BECKETT, MAKING CRIME PAY: LAW AND ORDER IN CONTEMPORARY American Politics 47 (1997); see also Harry A. Chernoff, Christopher M. Kelly \& John R. Kroger, Essay, The Politics of Crime, 33 HARV. J. ON LEGIS. 527, 533 (1996) (discussing Reagan's approach to crime). Other accounts, however, trace the federal interest in crime back to the beginning of the twentieth century. GOTTSCHALK, supra note 242, at 55-76. 
notion that the country was facing an epidemic of 'juvenile superpredators." "310

Federal criminal-adjudicative policy shifted accordingly. The absolute volume of federal criminal defendants had fluctuated substantially since World War II. It dropped in the late 1940s and 1950s due to declining immigration enforcement. But it began "surg[ing] between 1970 and 1977 and then [falling] back temporarily from 1977 to 1980," before growing "in almost every year from 1980." ${ }^{311}$ Indeed, the "number of federal criminal prosecutions has grown steadily, with little fluctuation, since 1980, at a rate of about 1,500 additional cases per year" with "a significant part" of that growth due to "the growing number of controlled substance prosecutions and stepped-up enforcement against immigration law violators." ${ }^{312}$ As a result, the number of federal offenders imprisoned for drug offenses ballooned from 4,900 in 1980 to 98,675 in $2007 .{ }^{313}$ From the perspective of the Supreme Court in the early 1980s, the then-incipient growth of federal criminal caseloads might have seemed to portend serious future pressures on federal dockets.

Given this constellation of factors-most of which would have been readily apparent to the Justices-it is possible to hypothesize that the incipient pressures of mass incarceration on the federal courts were not lost on the Court, even at the beginning of the 1980s. These pressures took the form of greatly increased volumes of suppression motions and habeas petitions (from both federal and state prisoners). Hence, during the period at which the fault rule was developed, the Court was at the acme of its institutional autonomy, and also inclined by habit and instruction to view the volume of litigation as not just a problem, but the defining problem for the federal courts. That problem, finally, likely seemed most pressing in the criminal law domain, where increasing reliance on the carceral

310. Nick Straley, Miller's Promise: Re-Evaluating Extreme Criminal Sentences for Children, 89 WASH. L. REV. 963, 990 (2014).

311. Ronald F. Wright, Trial Distortion and the End of Innocence in Federal Criminal Justice, 154 U. PA. L. REV. 79, 90-91 (2005).

312. Susan R. Klein \& Ingrid B. Grobey, Debunking Claims of Over-Federalization of Criminal Law, 62 EMORY L.J. 1, 16-17 (2012).

313. Anne R. Traum, Mass Incarceration at Sentencing, 64 HASTINGS L.J. 423, 429 (2013). For a more detailed account of the rise of mass incarceration, see Franklin E. Zimring, Imprisonment Rates and the New Politics of Criminal Punishment, in MASS IMPRISONMENT: Social CAUSES AND CONSEQUENCES 145, 145-46 (David Garland ed., 2001). 
state to solve social problems produced larger and larger caseload pressures on the federal judiciary. ${ }^{314}$

Can the rise of fault be explained as a response to rising crime rates without regard to the freestanding institutional concerns of the judiciary? There are a number of reasons for resisting this reductive conclusion. First, as already recounted ${ }^{315}$ the gatekeeping fault rule did not emerge solely at the behest of Justices appointed by presidents centrally concerned with crime control. Rather, it has been a bipartisan project.

Second, while Justices have expressed concern with crime control, they have since the 1950s repeatedly articulated their resistance to constitutional remediation in terms of the judiciary's institutional interest in caseload management. Part II.B contains many of these statements, ranging from Justice White's early concerns about the Fourth Amendment suppression remedy ${ }^{316}$ to Justice Breyer's concern about the burden of constitutional tort litigation in the lower courts. ${ }^{317}$ There is no reason to view these statements as disingenuous or false. Nor are such judicial expressions of concern over the institutional effects of constitutional remedies isolated. In respect to each line of ex post remedies doctrine examined above, Justices have repeatedly expressed concern about the manageability of litigation flows absent something like a fault rule. In the constitutional tort context, for example, Justice Black articulated a concern with "frivolous" suits in his Bivens dissent. ${ }^{318}$ In the habeas context, concerns about the "disproportionate amount of [judicial] time and energy" required for postconviction review have long been stock elements in the Court's opinions. ${ }^{319}$ And recently installed limits to the exclusionary rule have been underwritten by

314. It was well known that the then-nascent war on drugs would produce many more inmates. MiCHAEL TONRY, MALIGN NEGLECT: RACE, CRIME, AND PUNISHMENT IN AMERICA 4-7 (1995); see also DAVID GARland, THE CUlture OF CONTROL 131-32 (2001) (documenting the Reagan Administration's turn from rehabilitation to retributive theories of punishment). Hence, the Justices had good reason to be aware of how the number of suppression motions and habeas petitions would increase.

315. See supra Part II.B.

316. See supra note 272 and accompanying text.

317. See supra notes 260-261 and accompanying text.

318. Bivens v. Six Unknown Named Agents of Fed. Bureau of Narcotics, 403 U.S. 388, 42829 (1971) (Black, J., dissenting). In Harlow v. Fitzgerald, the Court expressed concern about the volume of $\S 1983$ cases, but expressed its concerns in terms of the "diversion of official energy" rather than the cost to the judiciary. Harlow v. Fitzgerald, 457 U.S. 800, 814 (1982).

319. Harris v. Reed, 489 U.S. 255, 282 n.6 (1989) (Kennedy, J., dissenting). 
worries about the "constant flood of alleged failures" to conform to the Fourth Amendment. ${ }^{320}$ Remedial reform is thus perceived by the Justices themselves as a response to the rising demand for adjudication, a demand that is plausibly linked to the recent growth and expected continued growth of the punitive, policing, and incarcerating state.

Evidence from the Justices' own lips, moreover, undermines another potential counterargument to the effect that a fault rule cannot be explained by caseload concerns because such a rule would not influence the behavior of habeas petitioners, the public defenders who represent most criminal defendants, or those aggrieved by perceived governmental abuse. The Leon Court, for example, worried that the availability of suppression would diminish the rate of plea bargaining. ${ }^{321}$ Empirical evidence that this is not so has done nothing to dent the force of the fault rule in the Fourth Amendment context. ${ }^{322}$ Setting the effect of suppression on plea bargaining to one side, though, it is hard to believe that the fault rule has not altered the incentives of plaintiffs' attorneys dependent on contingency-fee payoffs, public defenders determining how to ration scarce time and resources, ${ }^{323}$ or prisoners who may face real trade-offs in respect to how to allocate time and effort within prison. ${ }^{324}$ And even if the magnitude of these effects is in question, a fault rule might have distinctive appeal to the Justices because it is a legal intervention that has a clear judicial pedigree and feel, unlike (say) changes to substantive criminal law or the funding of either prosecutors' or criminal defenders' offices. It is not implausible, that is, to think of

320. See Hudson v. Michigan, 547 U.S. 586, 595 (2006).

321. United States v. Leon, 468 U.S. 897, 907 (1984).

322. See Thomas Y. Davies, A Hard Look at What We Know (and Still Need to Learn) About the "Costs" of the Exclusionary Rule: The NIJ Study and Other Studies of "Lost" Arrests, 1983 AM. B. \& Found. RES. J. 611, 668 (1983) (finding no evidence of an effect on plea bargaining).

323. For an argument that the Fourth Amendment exclusionary rule does create needless litigation, and that the resources it consumes would be better allocated elsewhere, see William J. Stuntz, The Virtues and Vices of the Exclusionary Rule, 20 HARV. J.L. \& PUB. POL'Y 443, 444 (1997) ("The exclusionary rule generates a lot of litigation-tens of thousands of contested suppression motions each year. That litigation is displacing something else, and the something else may well have more to do with guilt and innocence.").

324. For an impressive analysis of the hazards of incarceration, and the costly strategies necessary to navigate them, see generally DAVID SKARBEK, THE SOCIAL ORDER OF THE Underworld: How Prison Gangs Govern the American Penal System (2014). As Skarbek elegantly and comprehensively shows, the common caricature of a habeas petitioner idling away his days filing endless writs with no other demands on his time is simply unfounded. 
fault as an obvious first resort for a judge steeped in common-law ideas seeking to manage docket pressures. ${ }^{325}$ Finally, it is worth emphasizing that concerns about crime and judicial capacity not only can be complementary but can also interact: if institutional concerns were all that mattered, for example, it might simply have altered substantive law to be more favorable to plaintiffs, thereby encouraging higher settlement rates, or imposed constitutional constraints on substantive criminal law. Concern with crime removes these possibilities from the judicial agenda, and pushes the Court to deploy statist instruments to manage its dockets.

In tracing a causal chain from the political and social facts of mass incarceration to judicial doctrine, my argument here contrasts and conflicts with Professor William Stuntz's revered criticism of the Warren Court's criminal procedure cases. Stuntz argues that the judicial regulation of criminal procedure had a perverse effect because "the very existence of defendant-protective procedural doctrine tends to push toward lower funding and broader substantive criminal law. ${ }^{326}$ In this fashion, Stuntz suggests that doctrinal change conduced to larger institutional change. Stuntz's story, however, is hard to square with the chronological evidence. As Professor Stephen Schulhofer has explained, key changes to criminal sentencing are removed by decades from the Warren Court's criminal procedure decisions. ${ }^{327}$ Further, other Western nations that experienced the same punitive turn did so without any criminal procedure revolution against which to react, suggesting that "[p]rofound structural changes in Western industrial society lay at the heart of these developments, not judicial doctrine. ${ }^{\$ 328}$ But Schulhofer does not ask the logical next question: Did those "profound structural changes" influence doctrine in ways that alter the distribution, and at times the existence, of constitutional remediation? And if so, what mediated those effects? The argument developed here suggests that it did so via the judiciary's institutional concerns. For there is good reason to think that even if the Court has not shaped the development of criminal

325. I am grateful to Samuel Bray for this suggestion.

326. Stuntz, Uneasy Relationship, supra note 27, at 64 (emphasis omitted). Stuntz's claim has been understood as historical and causal in nature. See Robert Weisberg, Crime and Law: An American Tragedy, 125 HARV. L. REV. 1425, 1436 (2012) (explaining Stuntz's claim to be that "the noble commitment to constitutional procedure as a way of redressing the brutalities and inequalities of the criminal justice system was a disastrous historical turn").

327. Schulhofer, supra note 28 , at 1076-77.

328. Id. at 1078 . 
justice institutions, the latter have directly impinged upon its ability to respond to constitutional wrongs.

The Court, in short, had both the means and the motivation to translate its institutional autonomy into a fault-based regime of remedial rationing. Both historical and contemporaneous evidence suggest that judges in fact define their interests in institutional terms, and that managing the federal courts' caseload is central to their conception of this institutional interest. Against this backdrop, the innovations charted in Part I may have seemed like logical ways of vindicating the institutional independence of the federal judiciary. This diagnosis further suggests that the installation of the fault rule will prove relatively durable regardless of the ideological preferences of the next president to engage in significant appointments to the Court. Liberal or conservative, new Justices are likely to experience and endorse institutional perspectives on docket and case load management just as their ideological confreres have. To look to changing patterns of judicial appointment as a solvent of remedial rationing in the constitutional context, therefore, may be whistling in the wind.

\section{Institutional Interests and the Boundaries of the Fault Rule}

There is one final argument for glossing the fault rule as a function of institutional preferences, and not just as a grossly ideological effect. Under current doctrine, fault plays a regulative role with respect to some-but not all—channels of judicial review. Where it applies, fault operates as a tax on constitutional claim-making. It thereby disincentivizes claims. Where it does not apply, the absence of a fault rule is in effect a subsidy, making such challenges more attractive. By shifting the boundaries of fault, the Court elicits and also tamps down on different forms of claim-making. An examination of the contours of the Court's fault-based regime suggests that the current dispensation is well designed to maximize the federal bench's prestige while minimizing its labor costs. That is, the contours of the fault rule correspond to, and thereby promote, the institutional interests of the judiciary. ${ }^{329}$

Because this argument turns on some careful parsing of doctrine, I develop it in two stages. First, I identify contexts in which the Court

329. I do not mean to suggest that any and all judicial doctrine is explained by this mix of labor and prestige concerns, only that the detection of their influence here is further evidence that ideology and its fellow travelers are not the sole explanations for the rise of fault. 
has declined to install a fault rule. Second, I explain how the resulting doctrinal contours can be explained in terms of the judiciary's institutional interests. This account, while circumstantial, provides one more item of evidence for attributing fault-based rationing to the exercise of judicial independence.

1. Exceptions to the Fault Rule. Recall first that constitutional torts, suppression motions, and habeas petitions do not exhaust the universe of procedural mechanisms for constitutional claim-making. Courts also entertain asks for injunctive relief pursuant to Ex Parte Young ${ }^{330}$ and actions for declaratory relief ${ }^{331}$ Whereas rights claimants seeking relief using the former mechanism must demonstrate fault, ${ }^{332}$ litigants seeking the latter forms of relief need not show anything more than the bare fact of constitutional violation. In a Young action, a defendant might invoke traditional equitable doctrines of unclean hands ${ }^{333}$ and undue hardship, ${ }^{334}$ which both focus on a kind of fault. But few, if any, reported cases turn on these rules, suggesting that they do not play a large role in constitutional litigation. ${ }^{335}$ At least as a general matter, therefore, the availability of equitable relief in constitutional cases does not turn on fault.

There is, in short, a difference in the cost of asserting a constitutional right that depends on which procedural mechanism is employed. The ensuing differential in expected remedial value is amplified by the simple fact that injunctive and declarative forms of relief - unlike damages, suppression, or vacatur of a conviction-are typically available prophylactically before a violation has occurred. ${ }^{336}$ Prevention is generally more valuable than post hoc measures that

330. Ex Parte Young, 209 U.S. 123 (1908).

331. See supra notes $88-91$ and accompanying text.

332. See supra Part I.

333. See, e.g., Concilio de Salud Integral de Loiza, Inc. v. Perez-Perdomo, 551 F.3d 10, 11 (1st Cir. 2008) (rejecting injunctive relief on the basis of unclean hands).

334. See generally Douglas Laycock, The Neglected Defense of Undue Hardship and the Doctrinal Train Wreck of Boomer v. Atlantic Cement, 4 J. TORT L. 1 (2012). I have been unable to locate any reported case in which a Young remedy was denied because of undue hardship to the defendant.

335. In addition, neither the unclean hands doctrine nor the undue hardship doctrine train on the kind of fault described in Part I.

336. Moreover, sovereign immunity doctrine creates a supplemental incentive to seek forward-looking relief rather than compensatory damages. In Edelman v. Jordan, the Court hence distinguished permissible judicial orders that required the expenditure of funds to ensure future compliance with the Constitution, from an impermissible judicial order of "compensation" for past harm. Edelman v. Jordan, 415 U.S. 651, 667-68 (1974). 
rarely make plaintiffs entirely whole. As a result, "federal courts frequently entertain actions for injunctions and for declaratory relief aimed at preventing future activities that are reasonably likely or highly likely, but not absolutely certain, to take place." ${ }^{337}$

The 2013-14 Supreme Court Term provides illustrations. Susan B. Anthony List v. Driehaus ${ }^{338}$ involved a facial First Amendment challenge to an Ohio statute criminalizing false statements about candidates during political campaigns. ${ }^{339}$ Even though the only complaint against the plaintiffs at bar had been dismissed, the unanimous Court discerned a "substantial" enough "threat of future enforcement" to establish standing. ${ }^{340}$ The same term, in McCullen v. Coakley, ${ }^{341}$ the Court adjudicated another First Amendment challenge to a Massachusetts law establishing buffer zones around abortion clinics based on the plaintiffs' expressed desire to enter those zones in the future, rather than any past violation of the law. ${ }^{342}$ Anticipatory challenges of this ilk, of course, are not limited to the First Amendment context. ${ }^{343}$

The doctrine, however, contains another important wrinkle. Not all anticipatory suits are created equal. There is an important difference between "facial" challenges ${ }^{344}$ to the semantic content of the statute's text, such as in Susan B. Anthony List and McCullen, and challenges to ongoing institutional practices. Whereas facial challenges to laws face low hurdles, in City of Los Angeles v. Lyons, ${ }^{345}$ the Court imposed a high, often insurmountable, barrier to challenges to official practices by dint of a specific element of Article III standing rules. ${ }^{346}$

337. Clapper v. Amnesty Int'l USA, 133 S. Ct. 1138, 1160 (2013) (Breyer, J., dissenting).

338. Susan B. Anthony List v. Dreihaus, 134 S. Ct. 2334 (2014).

339. Id. at 2338 (quoting and discussing Ohio Rev. Code Ann. § 3517.21(B)).

340. Id. at 2340, 2345.

341. McCullen v. Coakley, 134 S. Ct. 2518 (2014).

342. Id. at 2527-28 (describing plaintiffs as previously complying with the Massachusetts buffer law).

343. See, e.g., Washington v. Glucksberg, 521 U.S. 702, 707 (1997) (describing the due process right to die); Planned Parenthood of Se. Pa v. Casey, 505 U.S. 833, 845 (1992) (plurality opinion) (describing the due process right to abortion).

344. See Gillian E. Metzger, Facial Challenges and Federalism, 105 COLUM. L. REV. 873, 877 (2005) ("What really distinguishes a facial challenge is not its breadth, but that it involves an attack on the general rule embodied in a statute.").

345. City of Los Angeles v. Lyons, 461 U.S. 95 (1983).

346. Id. at 97-98. 
To see how, consider the Court's divergent formulations of plaintiffs' threshold burdens in two cases. In Susan B. Anthony List, the plaintiffs satisfied Article III by showing that their conduct was "'arguably ... proscribed by [the] statute' they wish to challenge." "347 Simply based on the verbal content of the challenged Ohio statute, the unanimous Court had "no difficulty" concluding this threshold had been surmounted. ${ }^{348}$ In Lyons, a plaintiff seeking injunctive relief against a police chokehold practice was asked to make "the incredible assertion either, (1) that all police officers in Los Angeles always choke any citizen with whom they happen to have an encounter, whether for the purpose of arrest, issuing a citation or for questioning or, (2) that the City ordered or authorized police officers to act in such manner." ${ }^{349}$ Lyons in effect required a plaintiff challenging a practice to collate a large body of evidence, not just about what the law is, but about empirical regularities in the world. This is costly, often prohibitively so. Perhaps unsurprising, a 2000 analysis found that across 1,200 reported decisions applying Lyons 1,152 ended in dismissal on standing grounds. ${ }^{350}$

To summarize, the Court applies a fault rule to individualized tort actions, suppression motions, and habeas petitions-all of which challenge granular, singular official acts. No fault rule, however, applies to requests for prospective injunctive or declaratory relief against unconstitutional laws. Ex ante challenges to institutional practices, by contrast, while facing no fault rule, are impeded by Lyons rule. The net result is in some tension with the notional stated Supreme Court disfavor of hypothetical ${ }^{351}$ and facial ${ }^{352}$ requests for constitutional review: a relative subsidy for prophylactic facial

347. Susan B. Anthony List v. Dreihaus, 134 S. Ct. 2334, 2344 (2014) (quoting Babbitt v. United Farm Workers Nat'l Union, 442 U.S. 289, 298 (1979)).

348. Id.

349. Lyons, 461 U.S. at 106; see also Rizzo v. Goode, 423 U.S. 362, 380 (1976) (limiting the availability of ex ante relief against law enforcement officers on grounds that anticipate the Lyons analysis).

350. Myriam E. Gilles, Reinventing Structural Reform Litigation: Deputizing Private Citizens in the Enforcement of Civil Rights, 100 COLUM. L. REV. 1384, 1399 n.57 (2000).

351. Ala. State Fed'n of Labor v. McAdory, 325 U.S. 450, 461 (1945); accord Lewis v. Cont'l Bank Corp., 494 U.S. 472, 480 (1990); Sibron v. New York, 392 U.S. 40, 57 (1968).

352. See Nat'l Endowment for the Arts v. Finley, 524 U.S. 569, 580 (1998) (stating a preference for narrow, as-applied challenges as opposed to the "strong medicine" of facial invalidation (quoting Broadrick v. Oklahoma, 413 U.S. 601, 613 (1973))); accord United States v. Raines, 362 U.S. 17, 20-22 (1960); Yazoo \& Miss. Valley R.R. v. Jackson Vinegar Co., 226 U.S. 217, 219-20 (1912). 
challenges to laws, a relative tax on individualized claims and ex ante challenges to institutional practices.

2. Judicial Interests as a Determinant of the Contours of Fault. This doctrinal arrangement can be nicely explained by an account cognizant of the institutional interests of the judiciary. If we assume that judges' interests are refracted through an institutional lens, and thereby focused on managing the federal bench's workload, current doctrinal arrangements make surprising sense. To begin with, notice that caseload pressure can be more effectively relieved by regulating the broad river of ex post remedial demands rather than by staunching the comparatively small number of anticipatory requests for relief. Ex post remedies tends to be discrete rather than aggregate in nature, and hence more numerous. Different acts of police misconduct, different trial errors by prosecutors, and different judicial errors each require distinct suppression hearings, habeas petitions, and damages awards to determine facts and allocate relief. These accumulate, imposing a rising toll on judicial-economy ambitions. A fault rule that plays a gatekeeping function (such as qualified immunity or $\$ 2254(\mathrm{~d})(1)$ ) substitutes simple, mechanical protocols at the pretrial stage for complex, fact-intensive inquiries at trial. This has the effect of reducing trial costs, not to mention expenditures on the remedies portion of litigation. Even if a fault rule does not reduce the volume of these cases, it does render their adjudication less costly. It is far easier to determine whether there has been a clear and unambiguous violation of a constitutional rule than to determine whether there has been any constitutional violation. This has the supplemental benefit of enabling delegation to adjuncts such as staff attorneys and law clerks, thus easing the labor of adjudication. ${ }^{353}$

Similarly, the distinction between challenges to laws (such as Susan B. Anthony List) and challenges to institutional practices (such as Lyons) reflects the same concern about the managerial costs of different remedies. ${ }^{354}$ A challenge to an institutional practice may require a remedy that involves ongoing supervision and judicial involvement, whereas a challenge to a legal text can be resolved by

353. By contrast, other methods of mitigating case load burdens, such as "more detailed pleading and supporting affidavits," Fallon \& Meltzer, supra note 183, at 1821, might have the effect of sorting for nonfrivolous cases, but only by raising per capita decision costs.

354. Bray, supra note 91, at $1146 \mathrm{n} .247$ (noting that Lyons can be explained by the "emphatically managerial injunction" sought in that case). 
the fiat of a judicial order. By making the former easier to obtain than the latter, the Court eases the demand for judicial resources. ${ }^{355}$

This simple account can be supplemented by considering the bench's institutional interest in public reputation. ${ }^{356} \mathrm{~A}$ judicial interest in prestige explains both the extent of the fault rule, and its exceptions. Federal judges have long expressed their belief that "federal courts" are "'too important' for certain kinds of cases.",357 "Petty" cases are repudiated by leading jurists as ill-suited to federal adjudication. ${ }^{358}$ Doctrine and judicial lobbying affirms this belief. For example, the Court developed through common-law adjudication an "appellate review" model of administrative agency oversight as a means to avoid being called upon to decide "matters that were not properly judicial but were rather 'administrative' in nature." ${ }^{359}$ In effect, the appellate review model mitigated caseload demands created by the new federal regulatory state.

Federal judges also preserve their prestige by preventing inflation of the federal bench. Seventy-five years after it refined the appellate review model, the federal judiciary has been among the most important lobbies in Congress resisting the extension of the prestigious Article III badge to bankruptcy judges, ${ }^{360}$ while at the

355. Can these doctrinal distinctions also be explained in ideological terms? It is not implausible to think that challenges to laws have a different ideological valence to challenges to institutional practices. It suffices here to observe that doctrine advances both ideological and institutional interests, and it may be misleading and unnecessary to choose between the two.

356. See lee Epstein, William landes \& Richard Posner, The Behavior of Federal Judges: A TheORETICAL AND EMPIRICAL STUdy OF RATIONAL CHOICE 43, 48 (2013) (positing "the desire for a good reputation" as part of the judicial utility function).

357. Judith Resnik, Trial as Error, Jurisdiction as Injury: Transforming the Meaning of Article III, 113 HARV. L. REV. 924, 972 (2000) (tracing back arguments of this kind to Chief Justice Taft).

358. Felix Frankfurter \& Thomas G. Corcoran, Petty Federal Offenses and the Constitutional Guaranty of Trial by Jury, 39 HARV. L. REV. 917, 980-82 (1926) (arguing that the Constitution does not require Article III judges or juries to determine "petty" criminal cases); see also Interstate Commerce Comm'n v. Brimson, 154 U.S. 447, 456-57 (1893) (invalidating jurisdiction that required courts to engage in "administrative" rather than judicial functions).

359. Thomas W. Merrill, Article III, Agency Adjudication, and the Origins of the Appellate Review Model of Administrative Law, 111 COLUM. L. REV. 939, 944, 990 (2011) (describing the federal judiciary's "fear of contamination" by involvement in administration).

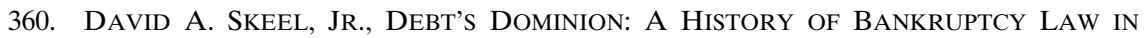
AMERICA 157-58 (2001) (documenting longer patterns of judicial resistance); Geraldine Mund, Appointed or Anointed: Judges, Congress, and the Passage of the Bankruptcy Act of 1978 Part Three: On the Hill, 81 AM. BANKR. L.J. 341, 346 n.18, 347-53 (2007) (describing various channels of influence from Chief Justice Burger and the federal judiciary into the drafting of the 1978 bankruptcy legislation, including formal testimony and backstage lobbying). 
same time (without discernable irony) invalidating the latter's review of state-law tort claims. ${ }^{361}$ This interest in preserving institutional prestige aligns with judges' interest in managing caseloads. Courts do not maximize their prestige by simply extending their dockets as far as possible. To the contrary, there is an inverse relationship between docket pressures and prestige. A bench with fewer, more interesting cases is, all else being equal, a more alluring and prestigious sinecure than one with a greater number of less interesting, more mundane cases. Efforts to insulate federal courts from the messy, unrewarding labor of adjudicating discrete, dispersed, and unglamorous constitutional violations result in more judicial time being available for more prestigious work. They are also consonant with a priority for high-profile challenges to laws-all the best to reinforce the impression that federal courts are (or wish to be) high-minded forums of principle, not mere fact-grubbers sorting through the detritus of the modern regulatory and police state. Cases such as Susan B. Anthony List and McCullen are exemplars of a species of prestigious, high-profile suits that are elicited by leaving unregulated the channels for injunctive or declaratory relief. The continued supply of these cases creates the impression of a Court diligent in its enforcement of the Constitution, even though the Court is spared the hard labor of vindicating most "petty" constitutional claims that arise from quotidian crime control and bureaucratic behavior. Hence, the argument from judicial economy developed here can also be understood in terms of the reputational interests of the federal courts.

$$
* * *
$$

This Part has developed evidence to the effect that the institutional interests of the judiciary have shaped the emergence of the fault role. I have not tried to show that such interests are exclusive of other concerns. Rather, I have explored the inadequacy of political and ideological explanations, and then developed the case for attributing some causal effect to the judiciary's institutional interest in case management. The net effect is to supply a more nuanced account of doctrinal change than the mechanically ideological stories that to date have dominated.

361. Stern v. Marshall, 131 S. Ct. 2594, 2601 (2011); see generally Anthony J. Casey \& Aziz Z. Huq, The Article III Problem in Bankruptcy, 82 U. CHI. L. REV. (forthcoming 2015), http://papers.ssrn.com/sol3/papers.cfm?abstract_id=2496468 [http://perma.cc/T2XG-EXRZ] (describing and criticizing this line of cases). 


\section{IMPLICATIONS OF THE FAULT RULE FOR CONSTITUTIONAL REMEDIES}

The primary aim of this Article is to describe how scarce judicial resources are allocated to the task of constitutional remedies, and to offer a hypothesis about one set of causal forces that to date have been largely ignored. This Part turns from that descriptive and analytic task to some normative implications of the causal claim advanced here. To be clear, the causal linkage between judicial independence and remedial rationing that I have proposed in Parts I and II raises a host of important puzzles. My aim here is not to resolve all of those questions, but rather to flag what strike me as the most important of them. Hence, I set forth some of the welfarist and distributive implications of fault-based rationing of remedial resources first, and then conclude by limning the consequences of the present analysis for standard accounts of the Separation of Powers.

\section{A. Distributive Implications}

The descriptive account offered in Parts I and II of this Article has illumined a doctrinal superstructure that imposes low transaction costs upon ex ante challenges to the verbal content of laws or regulation, and high transaction costs on both challenges to institutional practices, and also discrete requests for granular afterthe-fact remedies. The former, therefore, are prioritized over the latter. This resulting system of implicit taxes and subsidies on private behavior has complex welfarist and distributional implications. Characterization of these effects depends on how one defines social welfare-which is controversial-and whether one thinks distributional concerns are salient-which is also divisive. Rather than trying to answer these deep underlying questions, my aim here is to sketch briefly how constitutional remedies doctrine influences valuable social ends without trying to define conclusively what those goals should be. I focus on three vectors of welfare and distributional effects from the doctrinal arrangements mapped in this Article that run through, respectively, different sorts of constitutional errors, different rights, and different litigants. My aim here is not to pronounce judgments on those effects, but simply to elucidate their operation.

First, the Court's remedial doctrine entails that different kinds of constitutional errors receive different treatment. On the one hand, a constitutional flaw that is manifest on the face of a generally 
applicable statute or regulation, that operates directly against individuals as a primary rule without the intermediation of any prosecutorial discretion on the part of an enforcing agency, is most vulnerable to judicial correction. At the other end of the spectrum, a constitutionally flawed act or practice, unmemorialized in written text and dispersed through time and space in a sporadic, even stochastic, distribution, cannot be remedied ex ante. Instead, it will receive only the light review that can be exercised under the anesthetizing regime of the gross fault rule that covers ex post remedies. Stated otherwise, errors that occur during the liquidation of standards (which generally occurs after a violation) receive lighter judicial scrutiny than errors embedded in the formulation of a rule (which typically occurs before the violation) ${ }^{362}$ The doctrine hence creates a subtle tilt in favor of standards rather than rules where a risk of constitutional challenge is present.

Second, variation in the transaction costs of different remedies influences the distribution of resources available for the enforcement of distinct rights. The fault rule raises the cost of enforcement where it applies because it demands a more onerous showing by litigants. This differential in enforcement costs intersects with differences between rights. Some rights are easier to enforce ex ante with an injunction, while others are easier to enforce ex post by damages, suppression, or the vacatur of a conviction. Lowering the price of ex ante enforcement thus favors some rights over others. To pick an uncontroversial example, First Amendment and Due Process rights related to participation in the democratic process ${ }^{363}$ are most valuable when enforced prospectively, and lack obvious commensurable monetary substitutes. After an election has been resolved, and one candidate is selected over others, there may be no good way to mitigate fully infringements on democratic participation rights. ${ }^{364}$

362. For an analysis of the rules/standard distinction that underscores its temporal element, see Louis Kaplow, Rules Versus Standards: An Economic Analysis, 42 DUKE L.J. 557, 562 (1992).

363. See, e.g., Dunn v. Blumstein, 405 U.S. 330, 336 (1972) ("In decision after decision, this Court has made clear that a citizen has a constitutionally protected right to participate in elections on an equal basis with other citizens in the jurisdiction."); see also Burdick v. Takushi, 504 U.S. 428, 433-34 (1992); Bullock v. Carter, 405 U.S. 134, 143 (1972).

364. The analysis of aggregate voting rights (such as the rights of a particular ethnic or racial voting bloc) implicate a more complicated choice of temporal frame. See Adam B. Cox, The Temporal Dimension of Voting Rights, 93 VA. L. REV. 361, 372-73 (2007). Damages are sometimes awarded. See, e.g., Nixon v. Herndon, 273 U.S. 536, 540 (1927). 
Monetary damages would strike many as "hopelessly inadequate." Discrimination under the Equal Protection Clause can also be understood as the failure to treat members of a protected class "with dignity and respect." ${ }^{366}$ Again, compensatory remedies seem poorly fitted to the particular harm of being treated as less than human. Dignity is not typically thought to be fungible with cash.

On the other hand, there are many other rights that want for any prophylactic remedy, but are arguably addressed in a tolerable fashion via damages after the fact. In the takings context, for example, the Court has stated that a property owner must pursue compensation through state procedures before a Fifth Amendment takings claim will "ripen" for the purposes of federal-court adjudication, ${ }^{367}$ and has declined to permit any acceleration of takings claims even when the process of state-court adjudication generated preclusive effects that barred federal-court relitigation. ${ }^{368}$ This reflects a (perhaps erroneous) belief that ex post remedies are at least adequate for unconstitutional takings. Even in the absence of formal constraints on ex ante remedies, moreover, practical and epistemic constraints may also render ex post claims the only viable pathway. Illegal searches that generate no inculpatory evidence, for example, may not be predictable before the fact. Indeed, even in jurisdictions where unconstitutional searches and police violence are endemic, Lyons means the ex post channels of tort actions, suppression motions, and postconviction relief are the only game in town. It is this class of rights better suited to ex post enforcement that are disincentivized by the fault rule.

Finally, differences in remedial access will also differentiate between distinct categories of litigants, both on the plaintiff and on the state defendant side. Constitutional-rights claimants are likely sensitive to the costs of judicial enforcement. Litigants' epistemic and litigation resources influence the relative costs of different species of judicial remedy. An increase in the evidentiary showing or procedural

365. Cass R. Sunstein, Incommensurability and Valuation in Law, 92 MiCH. L. REV. 779, 785-90 (1994) (developing a more general account of incommensurability problems in the law).

366. Id. at 847-51 (discussing sex discrimination claims).

367. Williamson Cty. Reg'l Planning Comm'n v. Hamilton Bank, 473 U.S. 172, 194 (1985).

368. San Remo Hotel, L.P. v. City \& Cty. of San Francisco, 545 U.S. 323, 338 (2005). The net effect of Hamilton Bank and San Remo Hotel is not to deprive litigants of a federal forum; rather, it is to leave the Supreme Court's certiorari jurisdiction as the sole federal forum for certain takings claimants. Thomas W. Merrill, The Character of the Governmental Action, 36 VT. L. REV. 649, 656 (2012). 
hurdles necessary to secure monetary relief, for example, will therefore reduce expressed demand for that form of judicial enforcement. The expected value of injunctive relief will vary, by contrast, depending on the litigant's ability to anticipate and file suit prior to a governmental action. Along either margin, litigants' demand for constitutional remedies is likely to be elastic. ${ }^{369}$ Changes in the relative prices of remedies will thus change the pool of litigants seeking remedies.

Consider, for example, the Court's use of the fault rule to increase the cost of enforcing rights ex post relative to ex ante enforcement in many domains. In expectation, such a change will depress litigant demand for rights that can only be vindicated through monetary damages. At the same time, it will increase litigant demand in respect to rights that can only be vindicated fully by anticipatory intervention. It also lowers the cost of constitutional remediation for plaintiffs who have the epistemic and social resources to judicial assistance before a violation occurs, and increases the cost of such remediation for plaintiffs who lack the resources to act before the state does. Whether one looks at different effects between rights or litigants, therefore the result is the same: some litigants gain, while others lose out. Changes to the relative transaction costs of different remedies is thus a way for judges to change the mix of litigants that benefit from the expenditure of a fixed pool of taxpayer-supported judicial resources. ${ }^{370}$ Recalibrating remedies doctrine, in public choice terminology, is a vehicle for implicitly shifting the allocation of judicial resources between different interest groups.

Finally, it is not only rights claimants who are treated differently under the current remedial dispensation. The doctrine also distinguishes between different state defendants. The current remedial architecture channels judicial resources toward the scrutiny of centralized fonts of legal authority (such as legislators or

369. Cf. Francis E. McGovern, An Analysis of Mass Torts for Judges, 73 TEX. L. REV. 1821, 1845 (1995) ("[A] tort is elastic to the extent that the number of cases that are filed (demand) rises as the transaction costs associated with each case (price) are reduced and the number of judicial case resolutions increases (supply)."). Demand for judicial enforcement of some individual rights may be inelastic, such that increases in the price of judicial enforcement has no effect on the volume of litigation.

370. The quantity of resources allocated to the judicial budget, of course, can vary from year to year, although in recently years the federal judiciary's budget has been in decline. See CHIEF JUSTICE JOHN ROBERTS, 2013 YEAR-END REPORT ON THE FEDERAL JUDICIARY 4-5 (2013), http://www.supremecourt.gov/publicinfo/year-end/2013year-endreport.pdf [http://perma.cc/ 996U-3UHR] (describing a 5 percent reduction in the annual federal judicial budget). 
regulation-generating agencies), and away from dispersed, discretionexercising officials (such as line officials within dispersed bureaucracies, prosecutors and the police ${ }^{371}$ ). Consistent with the decentralizing impulse at the core of American federalism, the remedial doctrine described here makes it easier to challenge to concentrated, top-down forms of lawmaking, and at the same time raises the price of challenges to dispersed, localized exercises of delegated authority. This result is particularly striking in the policing context. Recent ethnographies of urban policing have underscored the frequency and severity of routine violence inflicted by line officers, in particular in African American communities. ${ }^{372}$ It is precisely the lowest visible forms of unconstitutional violence, which effect many of the least politically powerful communities in the United States, that the Court has rendered most difficult to remedy. This is consistent with Richard Posner, William Landes, and Lee Epstein's prediction that reduced access to federal courts "weighs most heavily on persons seeking to expand legal rights [such as] antidiscrimination rights [and] prisoners rights." ${ }^{373}$

Reasonable people will differ about whether these effects on different species of violations, different rights, and different litigants are warranted or lamentable, just as they disagree on how to prioritize between rights and litigants. I do not aim to settle those differences here. Nevertheless, this analysis should underscore the fact that the fault-based gatekeeping regime for allocating constitutional remedies, along with its doctrinal adjuncts, has significant downstream effects on important social goals-effects that are perhaps all the more surprising given the heterogeneous ideological composition of judicial coalitions responsible for that rule. The subtle way in which these effects arise means that they have never been subject to public scrutiny or debate. At a minimum, differences in ultimate normative priors should not undermine the conclusion that such sub rosa redistribution of the benefits that flow from our Constitution may be problematic simply because of its want of transparency.

371. See William J. Stuntz, The Political Constitution of Criminal Justice, 119 HARV. L. REV. 780, 799 n.104 (2006) (stating that Lyons "effectively barred injunctions as a remedy for police misconduct").

372. See GOFFMAN, supra note 5, at 71-72 (exploring effects of pervasive police violence on public attitudes and behavior).

373. EPSTEIN ET AL., supra note 356, at 41. 


\section{B. Implications for the Separation of Powers}

A second implication of this Article's analysis bears on Separation of Powers theory. The autonomy of the judiciary has long been conceived as a central plank of the Constitution's Separation of Powers. ${ }^{374}$ But the existence of a causal connection between judicial independence and a fault-based rule for limiting the availability of constitutional relief complicates the traditional account of the judiciary's role in the national government. At a minimum, it shows that the policy effects of judicial independence are more volatile than generally believed. Read more aggressively, the evidence presented here suggests that the successful institutionalization of judicial independence can undermine, as much as further, the project of realizing constitutional rights.

There is a deep-seated belief in American constitutional jurisprudence of a causal connection between the creation of judicial independence and the vindication of individual rights. The French political theorist Montesquieu, an influential figure among the Framers, cautioned that "liberty" would be lost "if the power of judging is not separate from the legislative power and from executive power." ${ }^{375}$ Introducing the Bill of Rights to the first Congress, James Madison prophesized that "independent tribunals of justice" would act "in a peculiar manner [as] the guardians of those rights" and "an impenetrable bulwark against every assumption of power in the Legislative or Executive." ${ }^{376}$ On this view, the purpose of judicial independence is to ensure that cases-especially those involving prized, basic rights-are decided on their legal merits (however defined) rather than on considerations of naked political power. ${ }^{377}$ Echoes of Madison's confidence in the social value of judicial independence resound repeatedly today. For example, Judge Deanall

374. Among "Madison and Hamilton at least, judicial independence was an essential aspect of the separation of powers." Stephen B. Burbank, The Architecture of Judicial Independence, 72 S. CAL. L. REV. 315, 320 (1999); see also JACK N. RAKOVE, ORIGINAL MEANINGS: Politics AND IDEAS IN THE MAKING OF THE CONSTITUTION 299 (1996) (noting that the Framers had "a substantive conception of the judiciary as the third branch of government").

375. 2 MONTESQUIEU, THE SPIRIT OF THE LAWS 157 (Cambridge ed. 1989) (1748) ("Nor is there liberty if the power of judging is not separate from the legislative power and from executive power .... If it were joined to executive power, the judge could have the force of an oppressor."); see also M.J.C. VILE, CONSTITUTIONALISM AND THE SEPARATION OF POWERS 96-97 (Liberty Fund 2d ed. 1998) (1967) (placing Montesquieu's argument in context).

376. 1 ANNALS OF CONG. 457 (1789).

377. John A. Ferejohn \& Larry D. Kramer, Independent Judges, Dependent Judiciary: Institutionalizing Judicial Restraint, 77 N.Y.U. L. REV. 962, 972 (2002). 
Tacha, while serving on the Tenth Circuit Court of Appeals, channeled conventional wisdom in pronouncing that "the independent federal judiciary has been a powerful tool in guarding the Constitution and the rights of individuals." ${ }^{378}$ Similarly, Solicitor General Archibald Cox hardly invited controversy when he called "[a]n independent judiciary... the best guarantee of liberty and impartial justice against executive oppression and other executive or bureaucratic abuse."379 The causal connection between judicial independence and the vindication of constitutional rights, in short, is, for all intents and purposes, conventional wisdom today.

The analysis developed in this Article suggests that conventional wisdom demands caveats. The institutionalization of judicial independence does not lead inexorably to the vindication of individual constitutional rights. Rather, the effects of endowing the federal courts with policy autonomy are contingent upon the interests and preferences of judges qua institutional actors. When judges' interests conduce away from the vindication of individual liberty interests, judicial independence will promote less, not more, respect for those rights. At least in the contemporary context, the institutional interests of federal judges have systematically pressed toward a constriction of remedial generosity. The result has been the transubstantive migration of the fault rule described in Part I. ${ }^{380}$

Separation of Powers theory concerning the judiciary from the Federalist 78 onward has focused on the negative proposition that judicial independence, and therefore the vindication of individual rights, simply requires that the courts by free of political influence. ${ }^{381}$ At least at the time of the Philadelphia Convention, this causal claim rested on theoretical premises rather than on experiential foundations. "[T] he division of executive and judicial power into two separate branches of government was a relative novelty in political

378. Deanell Reece Tacha, Independence of the Judiciary for the Third Century, 46 MERCER L. REV. 645, 645 (1995).

379. Archibald Cox, The Independence of the Judiciary: History and Purposes, $21 \mathrm{U}$. DAYTON L. REV. 565, 571 (1996).

380. The claim advanced here is distinct from the assertion that judges have class-based interests. See Louis Michael Seidman, Ambivalence and Accountability, 61 S. CAL. L. REV. 1571, 1581 (1988) (arguing that "independent judges are quite capable of confusing the public good with narrow ideological or class-based concerns"). I am concerned here with institutional, not ideological, motives.

381. See THE FEDERALIST No. 78, at 522 (Alexander Hamilton) (Jacob E. Cooke ed., 1961) (emphasizing the judiciary's lack of dependence). 
theory." ${ }^{382}$ Indeed, at least one element of the salient historical experience-the vigorous deployment of the habeas corpus writ by the King's Bench in England at the beginning of the seventeenth century-suggested that it was feasible to have robust judicial oversight of liberty-infringing governmental powers without the formal accouterments of judicial independence. ${ }^{383}$ Notwithstanding this experience, Separation of Powers theory assumes that the requirement of judicial as well as executive and legislative involvement in state-sponsored liberty deprivations will serve as a brake on the overzealous use of coercive power. ${ }^{384}$

But this is not necessarily so because of the self-defeating effects of institutionalizing judicial power. On the one hand, elected officials may have strong preferences for liberty that might be imposed on other, more recalcitrant state actors. Federal politicians, for example, sought to use federal courts to expand liberties in the teeth of state officials' opposition. ${ }^{385}$ The presence of multiple centers of political power, therefore, introduces the possibility that political control over the judiciary might lead to more libertarian outcomes. On the other hand, if judges' and rights holders' preferences slip out of alignment, judges may fail to pursue libertarian ends, or may pursue them with suboptimal lethargy. Separation of Powers theory, while expressing concern about political-branch capture of the judiciary, supplies no mechanism through which the judiciary's interests would become aligned with those of constitutional-rights holders. ${ }^{386}$ There is also no a priori reason to think that the preferences of those on the federal bench will accord with the maximal protection of individual rights. Certainly, the mere absence of overt and ongoing political control cannot easily be equated with a vigorous passion for liberty. The case

382. Ann Woolhandler, Judicial Deference to Administrative Action-A Revisionist History, 43 Admin. L. REV. 197, 214 (1991); see also GORDON WoOD, CREATION OF THE AMERICAN REPUBLIC 1777-1787, at 159-61 (1998) (discussing revolutionary-era difficulties "fit[ting] the judiciary into the scheme of government").

383. In the early 1600s, members of the King's Bench exercised a vigorous oversight of monarchical authority that became a paradigmatic model for later advocates of the Great Writ. PAUl HALlidAY, HABEAS CORPUS FROM ENGLAND TO EMPIRE 64-84 (2010).

384. For elegant modern restatements of this claim, see Rachel E. Barkow, Separation of Powers and the Criminal Law, 58 STAN. L. REV. 989, 1017 (2006); Rebecca L. Brown, Separated Powers and Ordered Liberty, 139 U. PA. L. REV. 1513, 1536-38, 1537 n.102 (1991).

385. See KeVIn MCMAHON, ReCONSIDERING RoOSEVElt On RACE 138, 150-75 (2004).

386. Note that the interests of different rights holders might conflict. See, e.g., Burwell v. Hobby Lobby Stores, Inc., 134 S. Ct. 2751 (2014) (resolving potential conflict between reproductive rights and religious liberty). There are many other examples. These show how hard it is to create an institution that protect the rights of all simultaneously. 
for tethering judicial independence to liberty becomes even more complicated when the Article II process of judicial selection is examined. For nothing in either the nomination-and-confirmation process or the institutional setting of a court leads inexorably to a rights-related mission. ${ }^{387}$ Moreover, it is hard to view the Court's history dispassionately and see a consistent and uniform commitment to all constitutional rights.

It gets worse: The historical and theoretical arguments developed here suggest that the more successful the courts are at building up their institutional autonomy, the more likely they may be to have distinct corporate interests that are at odds with the interests of constitutional-rights holders. That is, the very conditions that produce institutional stability for courts undermine the incentives necessary for judicial vigor in pursuit of individual liberty interests. Given this trade-off between institutional capacity and institutional incentives, it seems reasonable to hesitate before assuming that the courts will always and necessarily act in accord with stable libertarian preferences.

My analysis of the connection between judicial independence in its contemporary institutional form and the titration of constitutional remedies suggests that in the contest between institutional interests and concern for individual liberties, the latter has lost out as a historical matter. From the institutional perspective of federal courts, the constant stream of complaints thrown up by defective state courts, deficient police departments, and errant bureaucracies are a "petty" nuisance. ${ }^{388}$ The fault-based gatekeeping rule installed in the constitutional tort, habeas, and exclusionary rule contexts dramatically cuts down on the quanta of resources courts must allocate to these nuances. At the same time, it still leaves courts free to deal with more prestigious and higher profile facial challenges to laws that seek injunctive or declaratory relief.

Contemporary experience, in summary, suggests that when federal courts are allowed both the discretion and the instruments to follow through on their institutional preferences, the doctrinal results can be reduced enforcement of constitutional rights. It can also mean that many constitutional claimants never even obtain an opportunity

387. For an insightful analysis of the political forces that shape the judicial-appointment process, see David R. Stras, Book Review Essay, Understanding the New Politics of Judicial Appointments, 86 TEX. L. REV. 1033, 1047-72 (2008).

388. Frankfurter \& Corcoran, supra note 358, at 980. 
to be heard in court, but rather see their claims deflected via summary pretrial process. This will inevitably lead to cases in which individual rights claims are deprived of any day in federal court to vindicate a constitutional right either before or after the fact-all because of policy judgments taken by the federal courts. In this fashion, judicial independence in its institutional form can be at war with the vindication of individual rights.

The result here is consonant with a rich vein of scholarship expressly skeptical of the Separation of Powers. For example, Professor Elizabeth Magill has powerfully argued that the ideas of balance and separation between branches cannot be cashed out meaningfully because "in the contested cases, there is no principled way to distinguish between the relevant power" and "no way to measure the distribution of power among the branches at any point in time and no method to predict the effect of an institutional arrangement. ${ }^{\text {"389 }}$ Magill's work trains on the conceptual integrity of the Separation of Powers and its consequences for the overall political system, rather than the specific effects of judicial independence. Complementing Magill's account, Professors Daryl Levinson and Richard Pildes have argued that "the degree and kind of competition between the legislative and executive branches vary significantly, and may all but disappear, depending on whether the House, Senate, and presidency are divided or unified by political party., ${ }^{390}$

Supplementing that literature, this Article suggests that the effects of judicial independence-another mode of institutional separation of authorities - are far less constant or salutary than many have believed. Complementing work that excavates the limited ability of federal courts to vindicate constitutional rights in the face of political resistance, ${ }^{391}$ my excavation of the causal connection between judicial independence and constitutional remediation suggests that those who hope to realize the Bill of Rights' aspirations would do well not to follow its drafters advice: independent courts are not the

389. M. Elizabeth Magill, Beyond Powers and Branches in Separation of Powers Law, 150 U. PA. L. REV. 603, 604-05 (2001); see also M. Elizabeth Magill, The Real Separation in Separation of Powers Law, 86 VA. L. REV. 1127, 1155-57 (2000) (arguing that ideas of balance or separation provide no determinate answer to institutional design questions).

390. Levinson \& Pildes, supra note 31, at 2314.

391. See, e.g., Gerald N. Rosenberg, The Hollow Hope: CAN Courts Bring About Social CHANGE? (1991) (analyzing the limits of school desegregation litigation under the Equal Protection Clause). 
"peculiar ... guardians" of constitutional rights. Instead, judges may often be their most implacable foes precisely because of the judiciary's institutional interests.

\section{CONCLUSION}

The central goal of this Article has been to describe the rise of a fault-based system for rationing both process and remedies for constitutional violations, and to hypothesize one cause of that ascendancy that the literature has ignored. Since the early 1980s, that regime has diffused from constitutional tort jurisprudence to both the exclusionary rule and the postconviction habeas contexts. Scholars have failed to observe or study this doctrinal diffusion, or the concomitant unification of remedies doctrine across the three most frequently invoked mechanics for ex post redress for constitutional rights.

The rise of fault-based rationing, I have hypothesized, is not just a function of changing judicial ideology. It is also a consequence of an independent federal judiciary pursuing its interests and preferences by shaping doctrine. It thus flows, in some nontrivial measure, from our commitment to judicial independence at the institutional level. The resulting legal landscape raises many hard questions of how constitutional rights can, or should, be vindicated. At the very least, the analysis presented here should call into question any easy or quick reliance on the courts as the first and last best protectors of constitutional rights, at least so long as they are free to pursue their own institutional interests. 